\title{
Control in Beach and Dune Sands of the Gulf of Mexico and the Role of Nearby Rivers
}

\author{
Juan José Kasper-Zubillaga ${ }^{1}$, John S. Armstrong-Altrin ${ }^{1}$, Arturo Carranza-Edwards ${ }^{1}$, \\ Ofelia Morton-Bermea ${ }^{2}$, Rufino Lozano Santa $\mathrm{Cruz}^{3}$ \\ ${ }^{1}$ Instituto de Ciencias del Mar y Limnología, Unidad de Procesos Oceánicos y Costeros, Universidad Nacional Autónoma de México, \\ Ciudad de México, Mexico \\ ${ }^{2}$ Instituto de Geofísica, Exploración, Universidad Nacional Autónoma de México, Ciudad de México, Mexico \\ ${ }^{3}$ Instituto de Geología, Geoquímica, Universidad Nacional Autónoma de México, Ciudad de México, Mexico \\ Email: kasper@cmarl.unam.mx,john_arms@yahoo.com, arturo.carranza@gmail.com,omorton@geofisica.unam.mx, \\ rufino@unam.mx
}

Received August 14, 2013; revised September 11, 2013; accepted September 30, 2013

Copyright (C) 2013 Juan José Kasper-Zubillaga et al. This is an open access article distributed under the Creative Commons Attribution License, which permits unrestricted use, distribution, and reproduction in any medium, provided the original work is properly cited.

\begin{abstract}
A sedimentological, petrographic, and geochemical study of beach, dune, and river sands was carried out along the northwestern Gulf of Mexico. The main goal of this work is to show how beach and dune sands are controlled texturally, compositionally, and chemically by the nearby rivers for each beach location using a particle size analyser, a polarized microscope, a X-ray fluorescence and ICP mass spectrometer to obtain the following: grain-size values from one river (Carrizal River) are similar in range to their counterpart beach sands but not similar to the dune sands (Barra del Tordo). Rivers (Panuco and Carrizal) are compositionally controlling the quartz and feldspar contents of their counterpart beach and dune sands (i.e., Playa Miramar and Barra del Tordo). Rivers (Soto La Marina River) are directly influencing the composition of the beach sands (La Pesca) based upon the total quartz content, beach and dune sands. The concentration of magnetite grain fractions (Barra del Tordo beach and dune sands) is not under the influence of the nearby river (Carrizal River). In this case the compositional influence of beach and dune sands is related to sediment discharges by other fluvial systems, redistribution of the beach and dune sands along the coast and deflation/winnowing of light minerals. The Eu positive anomaly in the beach and dune sands from the three sites (i.e. Playa Miramar, Barra del Tordo, La Pesca) is linked to an increase in the $\mathrm{P}($ plagioclase $) / \mathrm{K}$ (potash feldspar) ratio. The $(\mathrm{La} / \mathrm{Lu})_{\text {cn }}$ highest ratio for river sands (Carrizal River) suggests quartz enrichment compared to their beach and dune sands counterparts. The $(\mathrm{Gd} / \mathrm{Yb})_{\mathrm{cn}}$ ratio for one river (i.e., Carrizal River) indicates that it is low in heavy rare earth elements. HREE compared to their beach and dune sands counterparts indicates less concentration of heavy minerals as potential carriers of HREE seawards.
\end{abstract}

Keywords: Beach; Dune; River; Sands; Petrology; Geochemistry; Gulf of Mexico

\section{Introduction}

Coastal sands (i.e., beach and dune systems) are compositionally controlled by chemical and mechanical factors such as waves, wind and long shore currents, deflation/ winnowing episodes, climate, relief, source composition, transport, and river discharges among others [1-8]. A wide range of techniques is used for grain size, mineralogical and geochemical determinations to investigate the compositional characteristics of coastal and fluvial sands. Such techniques are defined by grain-size laser analysis, point counting methods, heavy mineral associations, major, trace and rare earth elements analyses [9-15]. Furthermore, these techniques are helpful to understand the multifactorial roles that control the composition of coastal sands. The main goal of this paper is to show evidence of whether the river inputs near the beach and dune sites studied influence the sands composition or the beach and dune sands may be controlled by other coastal processes such as redistribution of sediments (recycling) and/or deflation/winnowing processes. In this paper, we show how the petrologic ternary diagrams and geochemical data sets, based upon major, trace and rare earth elements, can be useful to provide the compositional differences between beach and dune, and nearby river sands. Our hypothesis is that nearby rivers to the beaches studied may not be the only contributors to the sedimentological 
characteristics (i.e., grain-size, mineralogical and geochemical signatures) but some of the beach and dune systems may be influenced rather by redistribution of sediments along the coast and other mechanisms. Our major reliable control in obtaining the data was to sample in two different seasons of the year (i.e., dry and wet season).

\section{Study Area}

The study area is located in the coastal zone of the Tamaulipas State, Mexico (from $22^{\circ} 10^{\prime} \mathrm{N}-97^{\circ} 47^{\prime} \mathrm{W}$ to $\left.24^{\circ} 07^{\prime} \mathrm{N}-97^{\circ} 43^{\prime} \mathrm{W}\right)$. Sampling was carried out in three main coastal sites: Playa Miramar, Boca del Tordo, and La Pesca (Figure 1). Average beach width is $160 \mathrm{~m}, 42$ $\mathrm{m}$, and $89 \mathrm{~m}$ for each locality, respectively. Main rivers discharging in each site are Pánuco, Carrizal, and Soto La Marina, respectively.

\subsection{Geology}

The geology of the study area comprises Cretaceous limestones and shales in the Soto La Marina river basin, Cenozoic basic volcanic rocks and acid intrusive rocks in the Carrizal and Tigre river basins, Cenozoic shale, sandstone, conglomerate, and soils in Soto La Marina, Tamesis, and Panuco river basins (Figure 1). This area is considered a passive margin despite the fact that some volcanic outcrops are located in the central and northern portions of the Carrizal, Tigre, and Soto La Marina river basins although sands from modern environments will not always be placed in a passive margin classification when they are influenced by volcanic outcrops in the area [16].

According to Lugo-Hubp [17] the coastal area of Tamaulipas is part of the Coastal Plain of the Gulf of Mexico where fluvial erosion and deposition controls the composition and terranes of the southern coast. Additionally, some low altitude hills $(400 \mathrm{~m})$ can be observed near the coasts of southern Tamaulipas.

\subsection{Physical Oceanography}

In the southern coast of Tamaulipas, semidiurnal tides between 50 and $30 \mathrm{~cm}$ of amplitude occur [18]. Long shore currents are between $13 \mathrm{~cm} / \mathrm{s}$ to $18 \mathrm{~cm} / \mathrm{s}$ during the summer or dry season and 7.5 to $9 \mathrm{~cm} / \mathrm{s}$ during the winter or wet season [19]. Long shore currents have a northwesterly direction for both seasons, which is also evidenced by the presence of sand barrier spits attached to the coast with a northwesterly orientation. Waves are of 0.6 to $1.2 \mathrm{~m}$ in height with periods of 6 to $8 \mathrm{~s}$ with a northern direction.

\subsection{Climate, Precipitation, and Wind Regime}

The study area is located in the warm-temperate region of the Gulf of Mexico with temperatures from $28^{\circ} \mathrm{C}$ to $30^{\circ} \mathrm{C}$ in summer and $14^{\circ} \mathrm{C}$ to $20^{\circ} \mathrm{C}$ in winter [18]. Precipitation during the dry season is $160 \mathrm{~mm}$ and during the wet season it is $5.6 \mathrm{~cm}$, taking into account twomonth average precipitation rates belonging to both seasons. During the dry season, winds are from the north, east, northeast, and southeast with average velocities of 4 $\mathrm{m} / \mathrm{s}, 3 \mathrm{~m} / \mathrm{s}, 4 \mathrm{~m} / \mathrm{s}, 1.5 \mathrm{~m} / \mathrm{s}$, respectively. During the wet season winds average velocities are of $3 \mathrm{~m} / \mathrm{s}, 5 \mathrm{~m} / \mathrm{s}, 4$ $\mathrm{m} / \mathrm{s}$, and $3 \mathrm{~m} / \mathrm{s}$ with a northern, northeastern, eastern, and southeastern direction, respectively [20].

\section{Materials and Methods}

Approximately $200 \mathrm{~g}$ of sand samples were collected from the beach, dune and the three river systems close to the studied sites. The uppermost centimeter was sampled in order to ensure the homogeneity of the sand laminae [21]. Samples were taken at Playa Miramar, Barra del Tordo and La Pesca beaches, and the rivers Panuco, Carrizal, Soto La Marina during the dry (April) and wet (November) seasons (Table 1). A Global Positional System (GPS) was used to get the coordinates during the sampling procedure. Samples were located approximately $20 \mathrm{~m}$ from each other at each coastal site and taken from the inshore, foreshore, backshore at the beach and the stoss side of the dune. River sand samples were collected very close to the river mouth from south to north (Figure 1). Samples were dried and 1 to $2 \mathrm{~g}$ of sands was used for grain size analysis after storing $10 \mathrm{~g}$ of sample to ensure repeatability in the grain size analysis. The grain size analysis was carried out by means of a Laser Particle Size Analyzer (Model Coulter LS230) that determines the particle sizes between $-1.0 \phi$ and 14.6 $\phi$. Particle size distributions were given in $\mu \mathrm{m}$ and converted into $\phi$ units to calculate the grain size distribution parameters following Folk (5). Graphic mean was calculated using $\mathrm{Mz} \phi=(16 \phi+50 \phi+84 \phi) / 3$; sorting $\sigma \phi$ computed as $(84 \phi-16 \phi) / 4+(95 \phi-5 \phi) / 6.6$ and skewness is a measure of symmetry in a grain size distribution. Its value can be obtained with $16 \phi+84 \phi-2 \phi 50 / 2(84 \phi-$ $16 \phi)+95 \phi+5 \phi-2 \phi 50 / 2(95 \phi-5 \phi)$ (Table 1). Point counting was carried out using the Indiana method [22] (200 to 300 grains) for the major compositional framework of total quartz $(\mathrm{Q})$, total feldspar $(\mathrm{F})=\mathrm{K}$-feldspar $(\mathrm{K})+$ plagioclase $(\mathrm{P})$ and total lithics $(\mathrm{R})=$ volcanic + sedimentary + metamorphic + plutonic lithics $(\mathrm{Rv}+\mathrm{Rs}+\mathrm{Rm}$ $+p$ ), heavy minerals (HM) and biogenic (B) components (shells, algae, and corals) [23] (Table 2). Point counts were normalized to $100 \%$ and ternary diagrams for mineralogic data were plotted using confidence limits of the mean (CLM) at $99 \%$ of confidence level around the mean population of samples. These regions were constructed using the algorithm developed [24] and converted into ellipses using the Sigma Plot Software Ver- 


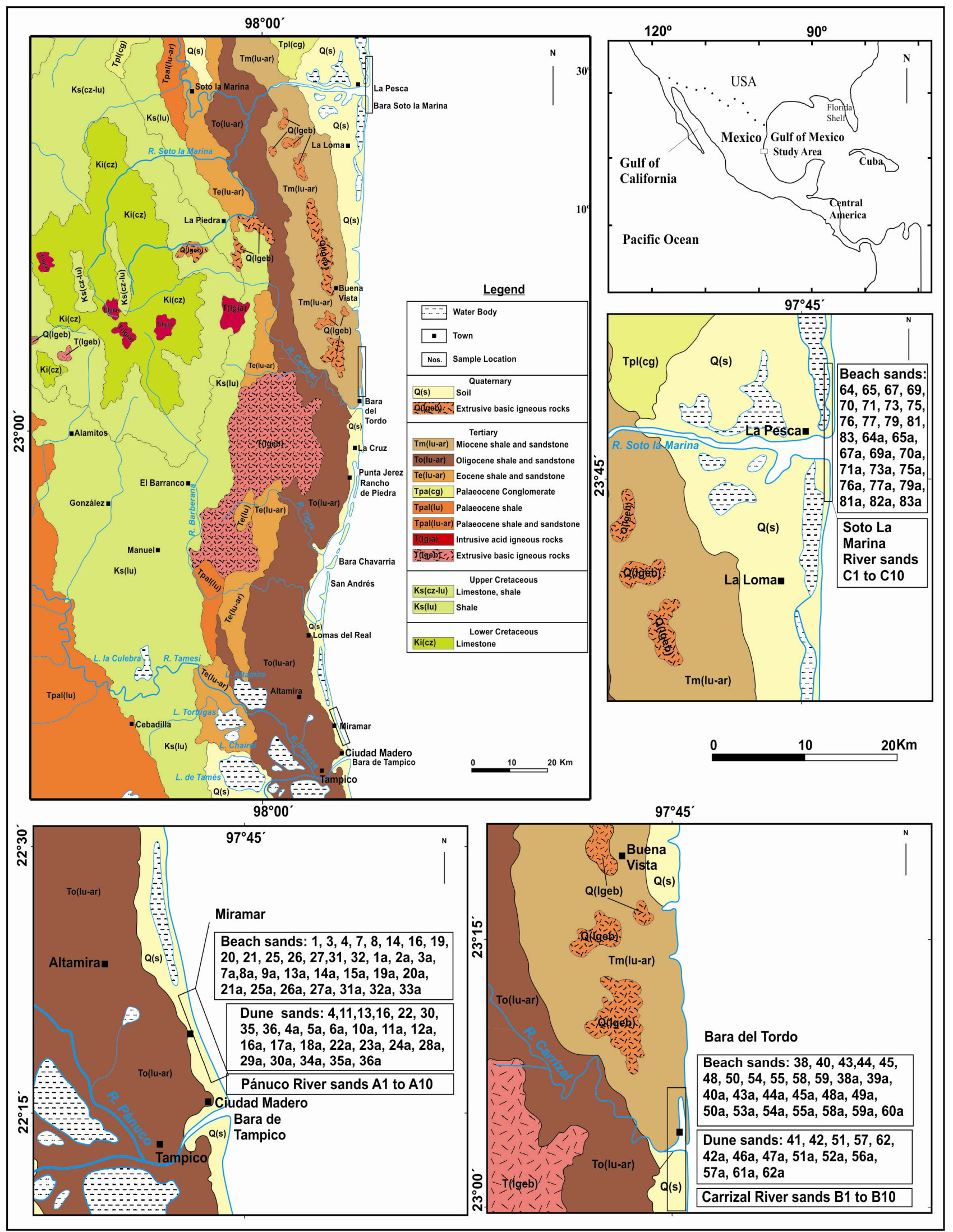

Figure 1. Geological map showing the study areas and sample locations. 
Table 1. Average textural parameters for the beach, dune, and river sands of the northwestern Gulf of Mexico.

\begin{tabular}{ccccccccc}
\hline & \multicolumn{3}{c}{ Playa Miramar } & \multicolumn{3}{c}{ Barra del Tordo } & \multicolumn{2}{c}{ La Pesca } \\
\hline & $\begin{array}{c}\text { Beach } \\
(\mathrm{n}=31)\end{array}$ & $\begin{array}{c}\text { Dune } \\
(\mathrm{n}=26)\end{array}$ & $\begin{array}{c}\text { River }^{1} \\
(\mathrm{n}=5)\end{array}$ & $\begin{array}{c}\text { Beach } \\
(\mathrm{n}=26)\end{array}$ & $\begin{array}{c}\text { Dune } \\
(\mathrm{n}=14)\end{array}$ & $\begin{array}{c}\text { River }^{2} \\
(\mathrm{n}=5)\end{array}$ & $\begin{array}{c}\text { Beach }_{(\mathrm{n}=33)} \\
\text { River }^{3} \\
(\mathrm{n}=5)\end{array}$ \\
\hline $\mathrm{Mz}(\phi)$ & $1.93 \pm 0.64$ & $2.27 \pm 0.50$ & $2.36 \pm 0.09$ & $2.14 \pm 0.19$ & $2.22 \pm 0.32$ & $1.93 \pm 0.50$ & $1.55 \pm 0.65$ & $1.80 \pm 0.76$ \\
$\sigma(\phi)$ & $0.62 \pm 0.28$ & $0.43 \pm 0.08$ & $0.42 \pm 0.03$ & $0.48 \pm 0.16$ & $0.47 \pm 0.25$ & $0.82 \pm 0.44$ & $0.74 \pm 0.33$ & $0.81 \pm 0.59$ \\
$\mathrm{Ski}$ & $-0.03 \pm 0.17$ & $-0.01 \pm 0.08$ & $0.11 \pm 0.19$ & $-0.05 \pm 0.12$ & $-0.02 \pm 0.11$ & $-0.21 \pm 0.21$ & $-0.03 \pm 0.23$ & $-0.24 \pm 0.40$ \\
$\mathrm{~K}_{\mathrm{G}}$ & $0.96 \pm 0.15$ & $0.99 \pm 0.09$ & $1.00 \pm 0.02$ & $1.05 \pm 0.31$ & $0.95 \pm 0.06$ & $1.04 \pm 0.20$ & $0.89 \pm 0.16$ & $1.02 \pm 0.32$ \\
\hline
\end{tabular}

$\mathrm{Mz}=$ mean grain size; $\sigma=$ sorting; Ski = skewness; $\mathrm{K}_{\mathrm{G}}=$ kurtosis; $\phi=$ phi units. ${ }^{1}$ Panuco River; ${ }^{2}$ Carrizal River; ${ }^{3}$ Soto La Marina River.

Table 2. Average compositional data for the beach, dune, and river sands of the northwestern Gulf of Mexico.

\begin{tabular}{|c|c|c|c|c|c|c|c|c|}
\hline & \multicolumn{3}{|c|}{ Playa Miramar } & \multicolumn{3}{|c|}{ Barra del Tordo } & \multicolumn{2}{|c|}{ La Pesca } \\
\hline & $\begin{array}{c}\text { Beach } \\
(\mathrm{n}=25)\end{array}$ & $\begin{array}{c}\text { Dune } \\
(\mathrm{n}=21)\end{array}$ & $\begin{array}{c}\text { River }^{1} \\
(\mathrm{n}=10)\end{array}$ & $\begin{array}{c}\text { Beach } \\
(\mathrm{n}=21)\end{array}$ & $\begin{array}{c}\text { Dune } \\
(\mathrm{n}=20)\end{array}$ & $\begin{array}{c}\text { River }^{2} \\
(\mathrm{n}=10)\end{array}$ & $\begin{array}{c}\text { Beach } \\
(\mathrm{n}=27)\end{array}$ & $\begin{array}{c}\text { River }^{3} \\
(\mathrm{n}=10)\end{array}$ \\
\hline Q & $198 \pm 55$ & $246 \pm 14$ & $261 \pm 13$ & $222 \pm 35$ & $232 \pm 45$ & $248 \pm 23$ & $212 \pm 44$ & $249 \pm 28$ \\
\hline $\mathrm{K}$ & $1.6 \pm 1.5$ & $2.1 \pm 1.9$ & $2.8 \pm 1.93$ & $2.7 \pm 3.0$ & $2 \pm 2.64$ & $1.0 \pm 1.1$ & $0.78 \pm 0.85$ & $2.0 \pm 1.5$ \\
\hline $\mathrm{P}$ & $3.3 \pm 3.3$ & $4.1 \pm 2.5$ & $1.5 \pm 1.72$ & $3.9 \pm 5.4$ & $3.75 \pm 7.48$ & $1.8 \pm 2.4$ & $1.59 \pm 1.50$ & $0.7 \pm 1.1$ \\
\hline $\mathrm{Rv}$ & $6.6 \pm 4.2$ & $5.6 \pm 3.9$ & $3.2 \pm 3.82$ & $5.2 \pm 5.4$ & $3.55 \pm 3.59$ & $3.3 \pm 3.3$ & $5.85 \pm 3.24$ & $2.0 \pm 2.1$ \\
\hline Rs & $10.2 \pm 5.2$ & $11.2 \pm 5.3$ & $6.6 \pm 2.41$ & $6.9 \pm 3.1$ & $5.65 \pm 3.50$ & $3.3 \pm 2.4$ & $5.81 \pm 3.39$ & $4.4 \pm 3.0$ \\
\hline $\mathrm{Rm}$ & $0.3 \pm 0.7$ & $0.4 \pm 0.6$ & $0.1 \pm 0.32$ & $0.2 \pm 0.5$ & $0.3 \pm 0.8$ & $0.1 \pm 0.3$ & $0.19 \pm 0.62$ & - \\
\hline $\mathrm{Rp}$ & $2.2 \pm 2.1$ & $3.0 \pm 2.6$ & $2.4 \pm 1.90$ & $1.8 \pm 2.7$ & $1.0 \pm 1.2$ & $0.2 \pm 0.4$ & $1.63 \pm 1.96$ & $1.0 \pm 1.2$ \\
\hline $\mathrm{HM}$ & - & $0.6 \pm 1.6$ & - & $4.2 \pm 7.4$ & $12.7 \pm 15.1$ & - & - & $0.5 \pm 0.7$ \\
\hline B & $78 \pm 58$ & $27.2 \pm 9.9$ & $22.5 \pm 8.42$ & $39 \pm 12$ & $39 \pm 29$ & $42.6 \pm 20.5$ & $72.0 \pm 46.6$ & $40.8 \pm 25.6$ \\
\hline Total $^{4}$ & 300 & 300 & 300 & 300 & 300 & 300 & 300 & 300 \\
\hline
\end{tabular}

$\mathrm{Q}=$ total quartz, $\mathrm{K}=$ potash feldspar, $\mathrm{P}=$ plagioclase, $\mathrm{Rv}=$ volcanic lithics (basalts, andesites), Rs = sedimentary lithics (limestones, chert, sandstones, shales), $\mathrm{Rm}=$ metamorphic (schist), $\mathrm{Rp}=$ plutonic lithics (granite), $\mathrm{F}=\mathrm{K}+\mathrm{P} ; \mathrm{R}=\mathrm{Rv}+\mathrm{Rs}+\mathrm{Rm}+\mathrm{p} ; \mathrm{HM}=$ heavy minerals (magnetite, hematite, zircon), $\mathrm{B}=$ biogenic fraction (shell fragments, algae). ${ }^{1}$ Panuco River; ${ }^{2}$ Carrizal River; ${ }^{3}$ Soto La Marina River; ${ }^{4}$ Total number of grains counted.

sion 2001. The ellipses represent the area in which samples might have variations in relation to the mean. This implies that the CLM define rigorously if two mean populations are significantly different.

Tables presented in the manuscript are the average results of extensive data that are included as repository data and table for the readers.

Sand samples were dried at $110^{\circ} \mathrm{C}$ and treated with lithium meta and tetraborate to make pressed powder pellets. They were analyzed using an X-ray fluorescence Siemens SRS 3000 equipment for major and trace elements $(n=60)$. For major and trace elements precision is valuated in terms of relative standard deviation being $<1 \%$. Trace elements were normalized using the upper continental crust values [25].

The Rare Earth Elements (REE) analysis was carried out for thirty eight sand samples by using $0.1 \mathrm{~g}$ of dried sample (mesh 200) and digested with strong acid. Digestion was performed in teflon vessels using $4 \mathrm{ml}$ of $\mathrm{HClO}_{4}$ and $10 \mathrm{ml} \mathrm{HF}$. This mixture was heated and residue was dissolved in distilled water and incorporated to a volumetric flask. Determination of REE was carried out with an ICP mass spectrometer VG Elemental model $\mathrm{PQ}_{3}$. Detection limits were calculated as the concentration equivalent to three times the standard deviation of five repli- cates of the blank solution. It was better than $200 \mathrm{ppt}$ for all elements determined. Calibration of the apparatus was done with a $0.1,1,10$ and 100 ppb multi-elemental standard solution (SPEX-High Purity) and a blank solution of de-ionized water all containing $\mathrm{HNO}_{3}$ at $2 \%$. Results were observed for international standards (JG-2). The validity of the analytical procedure was assessed by means of accuracy and precision tests. They were calculated by comparing measured and reference values (JA2). All elements determined had a better than $10 \%$ relative standard deviation (RSD) precision. Data resulted for BCU-3 or in "house standard" indicated good agreement with the certified values. The rare earth elements were normalized using the chondrite values [25].

\section{Results}

\subsection{Grain Size Parameters}

Playa Miramar beach, dune and river sands are coarse to fine-grained, poorly to moderately well sorted sands (Table 1). They are symmetrical with some beach samples showing fine to coarse-skewed trends platykurtic to mesokurtic (i.e. beach sands) and mesokurtic curves (i.e. dune and river sands).

Barra del Tordo beach, dune and river sands are me- 
dium to fine-grained, poorly to well sorted sands (i.e. some beach and river sands) with symmetrical (i.e. some beach, river and all dune sands) and coarse-skewed distributions and mostly mesokurtic curves.

La Pesca beach and river sands are coarse (i.e. some beach sands) to fine-grained (i.e. all river sands) poorly to moderately sorted sands and fine to coarse-skewed trends. They show platykurtic to leptokurtic curves. The best correlations of the three sand samples are between Mz $(\varphi)$ and $\sigma(\varphi)$ at Playa Miramar, Barra del Tordo and La Pesca for the beach sands at Playa Miramar $(r=-0.92)$ and beach and river sands at La Pesca $(r=-0.95 ; \mathrm{r}=$ -0.85 , respectively) and the beach $(\mathrm{r}=0.74)$ and dune sands $(r=-0.95)$ at Barra del Tordo (Figures 2-4). Correlations between $\mathrm{Mz}(\varphi)$ and Ski were significant at Barra del Tordo beach, dune and river sands (Figure 3(b)) showing symmetrical curves in the dune sand samples, in exception some river and beach sands are coarse skewed. The only significant correlation between $\mathrm{Mz}$ and $\mathrm{K}_{\mathrm{G}}$ was at Barra del Tordo dune sands and La Pesca beach sands (Figures 3(c) and 4(c)).

\subsection{Modal Analysis}

Using the Q-F-R ternary diagrams (Figure 5 and Table 3) it is observed that the beach, dune and river sands of Playa Miramar (beach $=\mathrm{Q}_{88}: \mathrm{F}_{3}: \mathrm{R}_{9} ;$ dune $=\mathrm{Q}_{90}: \mathrm{F}_{2}: \mathrm{R}_{7}$; river $=$ $\mathrm{Q}_{94}: \mathrm{F}_{2}: \mathrm{R}_{4}$ ), Barra del Tordo (beach $=\mathrm{Q}_{91}: \mathrm{F}_{3}: \mathrm{R}_{6} ;$ dune $=$ $\mathrm{Q}_{93}: \mathrm{F}_{3}: \mathrm{R}_{4} ;$ river $=\mathrm{Q}_{96}: \mathrm{F}_{1}: \mathrm{R}_{3}$ ) and La Pesca (beach $=$ $\mathrm{Q}_{93}: \mathrm{F}_{1}: \mathrm{R}_{6} ;$ dune $=\mathrm{Q}_{96}: \mathrm{F}_{1}: \mathrm{R}_{3}$ ) are quartzitic. However, it seems that there are significant differences in the composition of beach, dune and river sands between Playa Miramar and Barra del Tordo, supported by the position and size of the CLM in the Q-F-R diagram $[8,24]$ (Figure 5).

Quartz grains are mostly subangular to rounded (Figures 6(a) and (c)) in all the sand samples (beach, dune and river) and the volcanic rock fragments observed were basalts and probably andesites. Sedimentary rocks were mainly limestones, chert, sandstones and shales. Metamorphic fragments observed were probably schists. Also, plutonic lithics (i.e. granites and granodiorites) (Figure 6 (a)) were observed. Magnetite was the most abundant heavy mineral (Figure 6(b)) in the sands and the biogenic fraction was composed of shell fragments and probably algae.

When plotting the sand samples in the $\mathrm{Rv}-\mathrm{Rs}-\mathrm{Rm}+\mathrm{p}$ ternary diagram it is observed that La Pesca beach sands are enriched with Rv compared to the rest of the sites but the Soto La Marina River shows depletion in Rv. Beach and dune sands are enriched in Rs in Miramar and Barra del Tordo beaches. The Panuco and Carrizal River sands have a mix of Rv, Rs and $\mathrm{Rm}+\mathrm{p}$ fractions (Figure 7). Higher dispersal of the CLM area of the river sands in the ternary diagrams compared to the beach and dune
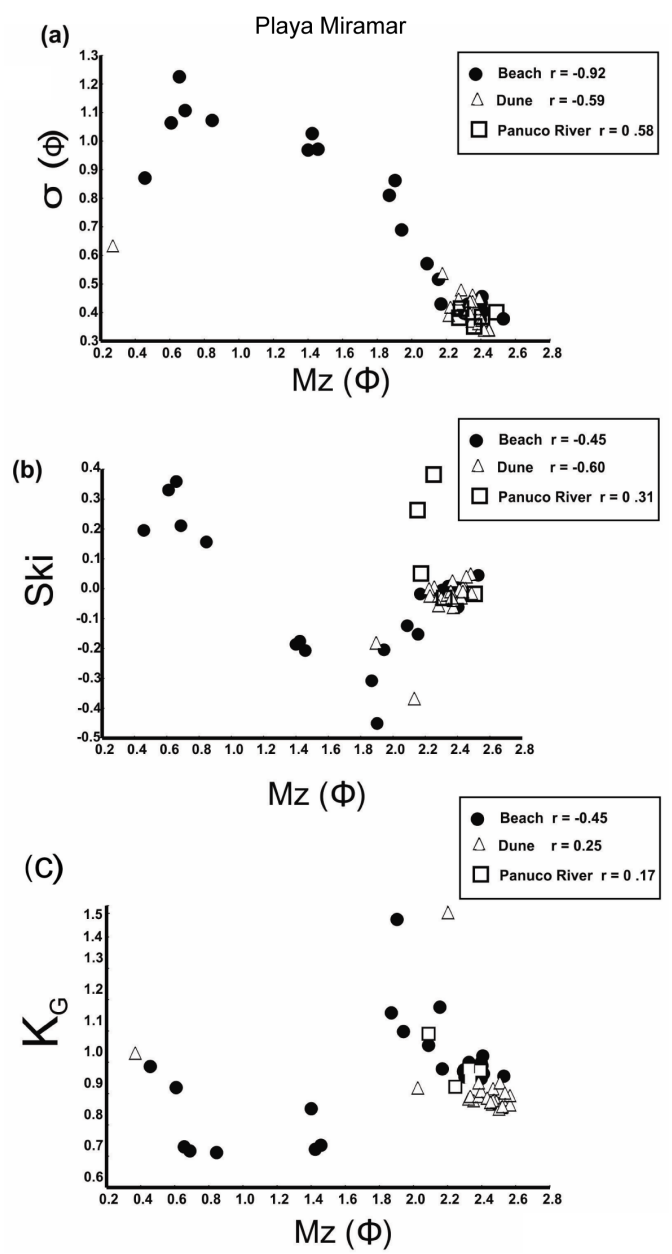

Figure 2. Bivariate plots for the beach, dune and river sands of Playa Miramar. (a) $\mathrm{Mz}-\sigma[\mathrm{Mz}=$ grain size expressed in $\Phi$ units; $\sigma=$ sorting expressed in $\Phi$ units]; (b) $\mathbf{M z}$ - Ski [Ski = skewness]; (c) $M z-K_{G}\left[K_{G}=\right.$ kurtosis $]$.

sands is due to small number of river sands and the heterogeneous supply of lithic fractions, which increases the CLM size. Heavy minerals mainly composed of magnetite grains are higher in the Barra del Tordo dune sands compared to the rest of the locations (Table 2). The biogenic fraction (B) is composed mainly of shell fragments and some algae and it is high for the three sedimentary environments (Table 2).

\subsection{Major Provinces Based Upon Geochemical Data}

The provenance discriminant function diagrams [26] (Figure 8) shows that there are three major provinces, which influence the composition of the beach, dune and river sands: the quartzose, intermediate and felsic provinces being the Carrizal River sands placed in the intermediate igneous province, whereas the beach and dune sands from Barra del Tordo are located in the quartzose sedimentary and felsic igneous provinces. 

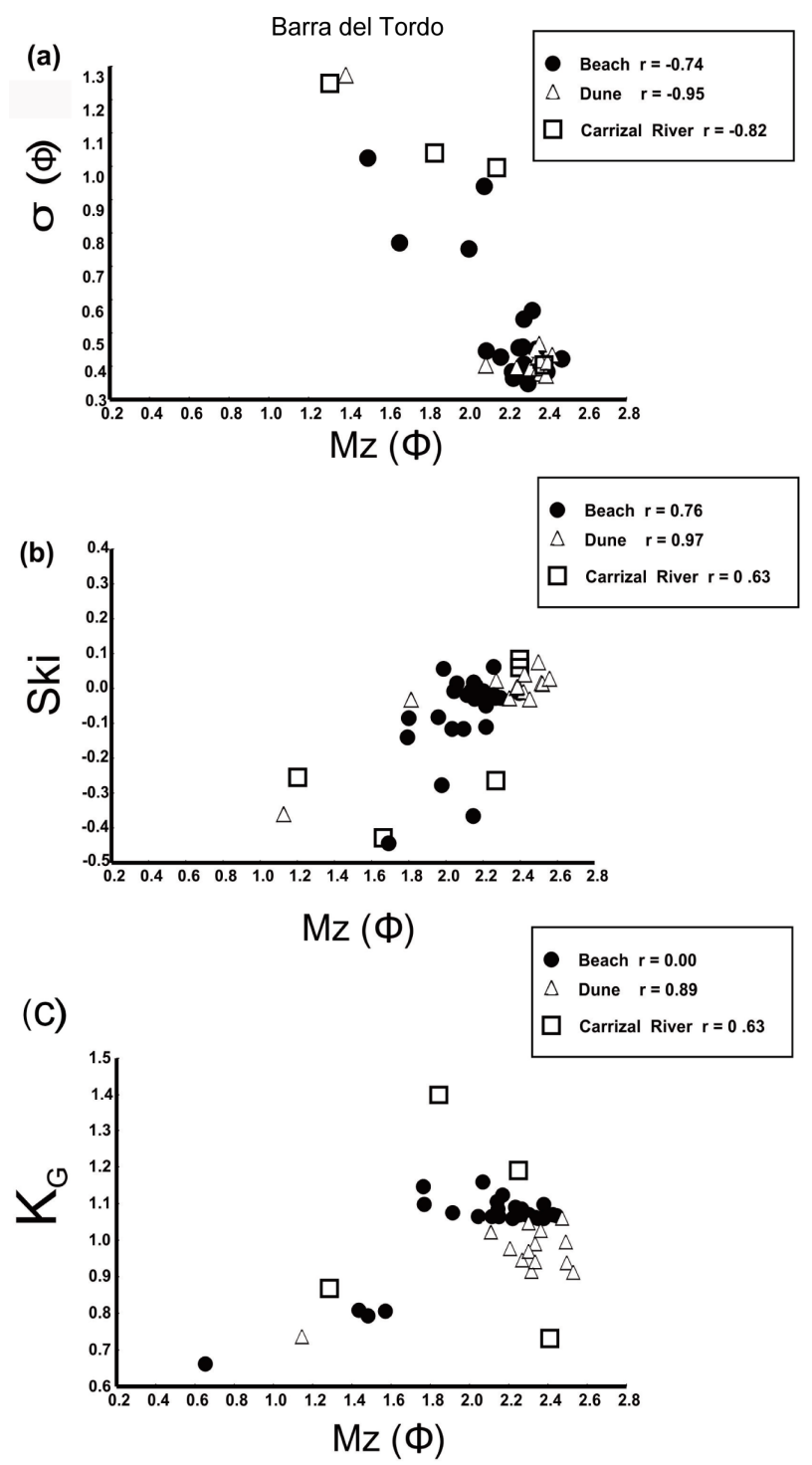

Figure 3. Bivariate plots for the beach, dune and river sands of Barra del Tordo. (a) $\mathrm{Mz}-\sigma[\mathrm{Mz}=$ grain size expressed in $\Phi$ units; $\sigma=$ sorting expressed in $\Phi$ units]; (b) Mz - Ski [Ski = skewness $]$; (c) $M z-K_{G}\left[K_{G}=\right.$ kurtosis $]$.

\subsection{Trace Element Geochemistry}

Average upper continental crust normalized data [25] of trace elements shows a more conspicuous concentration of $\mathrm{Sr}, \mathrm{Zr}, \mathrm{Nb}, \mathrm{Co}$ and $\mathrm{Cu}$ and depletion of $\mathrm{Th}, \mathrm{Ba}, \mathrm{Ni}$ and $\mathrm{V}$ for the beach, dune and river sands at the three beach sites (Figures 9(a)-(c) and Table 4). The higher concentration of $\mathrm{Co}, \mathrm{Sr}, \mathrm{Y}$ and $\mathrm{Nb}$ is observed for the rivers Panuco, Carrizal and Soto La Marina compared to their counterparts Playa Miramar, Barra del Tordo and La Pesca, respectively. Depletion of $\mathrm{Cr}$ is observed for the Carrizal and Soto La Marina River sands compared to Barra del Tordo and La Pesca beach and dune sands. Also the Soto La Marina river sands show the highest concentration of $\mathrm{Y}, \mathrm{Nb}$ and $\mathrm{Co}$ among the whole set of sand samples.

\subsection{Rare Earth Elements}

The results of REE analysis for the three sites are given in Table 5 and are shown as the average chondrite normalized patterns in Figures 10(a)-(c). There is a depletion of REE concentration especially for the Panuco and Carrizal River sands compared to the beach and dune sands from the Playa Miramar and Barra del Tordo sites. A Eu positive anomaly is observed for the beach, dune and river sands at Playa Miramar and La Pesca and river sands at Barra del Tordo.

\section{6. $\mathrm{SiO}_{2} / \mathrm{Al}_{2} \mathrm{O}_{3}$ versus $\mathrm{K}_{2} \mathrm{O} / \mathrm{Na}_{2} \mathrm{O}$ Binary Diagram}

On a $\mathrm{SiO}_{2} / \mathrm{Al}_{2} \mathrm{O}_{3}$ versus $\mathrm{K}_{2} \mathrm{O} / \mathrm{Na}_{2} \mathrm{O}$ diagram (Figures 11(a)-(c)) most of the data of this work plot close to the data coming from

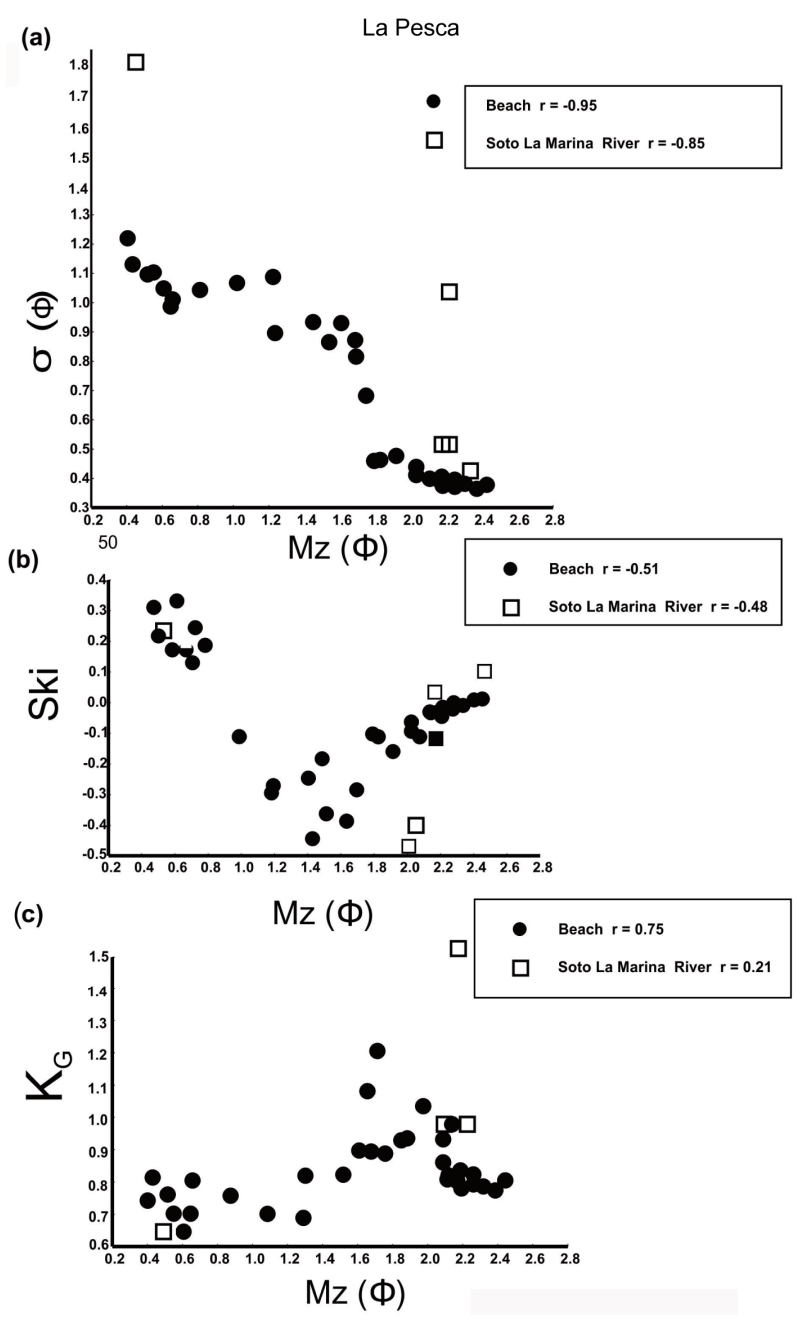

Figure 4. Bivariate plots for the beach, dune and river sands of Soto La Marina. (a) $\mathrm{Mz}-\sigma[\mathrm{Mz}=$ grain size expressed in $\Phi$ units; $\sigma=$ sorting expressed in $\Phi$ units]; (b) Mz - Ski [Ski = skewness $]$; (c) $\mathbf{M z}-\mathbf{K}_{\mathbf{G}}\left[\mathrm{K}_{\mathrm{G}}=\right.$ kurtosis $]$. 
(a)
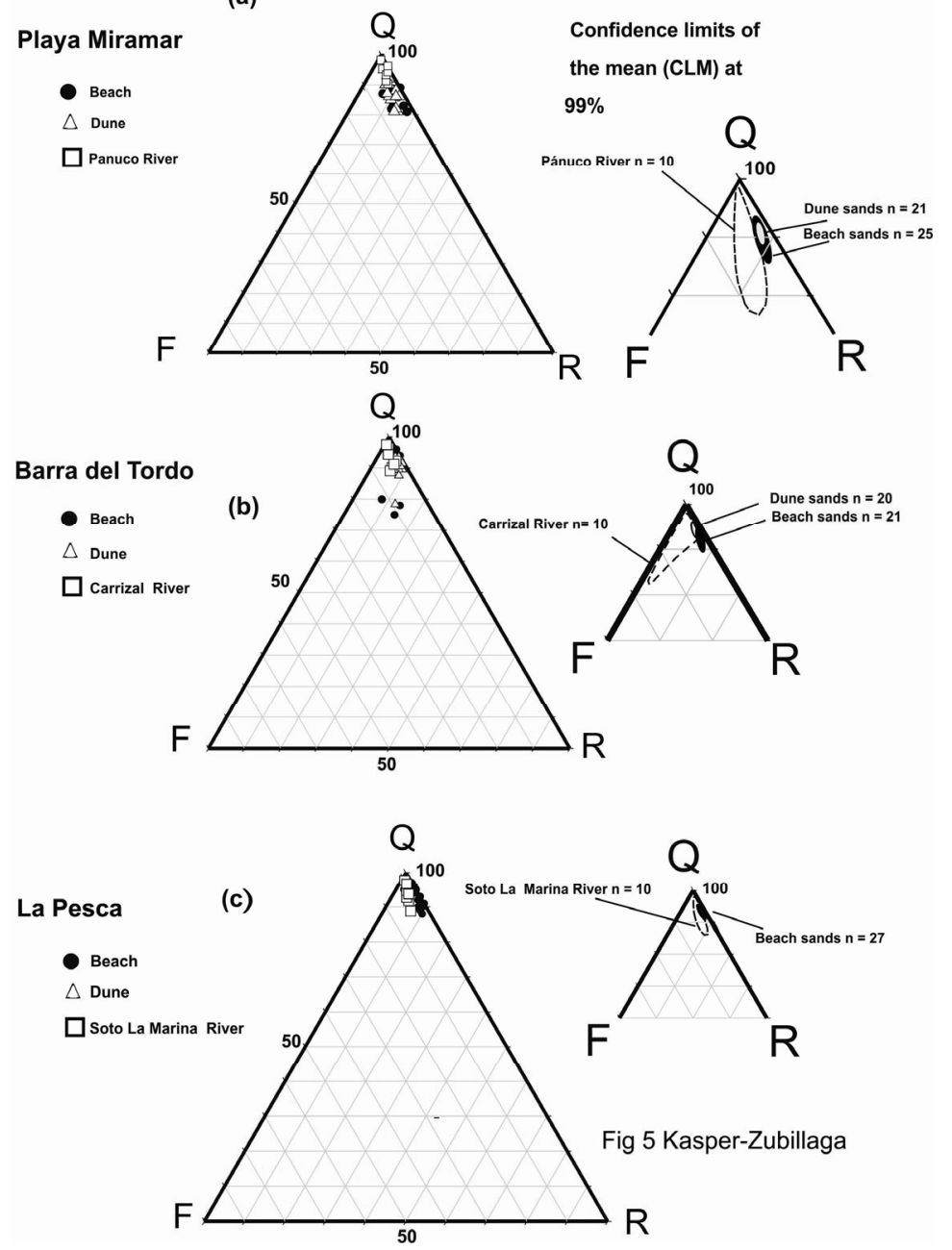

Figure 5. Q-F-R ternary diagram for (a) Playa Miramar, (b) Barra del Tordo and (c) La Pesca beach, dune and river sands with confidence limits of the mean (CLM) at $99 \%$ of confidence level (Weltje 2002). Q, total quartz; F, total feldspar [K-feldspar (K) + plagioclase (P)]; R, total lithics [volcanic (Rv) + sedimentary $(\mathbf{R s})+$ metamorphic $(\mathbf{R m})+$ plutonic $(\mathbf{p})]$; $\mathbf{n}=$ number of samples.

Table 3. Average trace elements data (ppm) for the beach, dune, and river sands of the northwestern Gulf of Mexico.

\begin{tabular}{|c|c|c|c|c|c|c|c|c|}
\hline & \multicolumn{3}{|c|}{ Playa Miramar } & \multicolumn{3}{|c|}{ Barra del Tordo } & \multicolumn{2}{|c|}{ La Pesca } \\
\hline & Beach & Dune & River $^{1}$ & Beach & Dune & River $^{2}$ & Beach & River $^{3}$ \\
\hline $\mathrm{Ba}$ & $286 \pm 79$ & $254 \pm 128$ & $375 \pm 174$ & $311 \pm 84$ & $259 \pm 78$ & $183 \pm 83$ & $291 \pm 64$ & $486 \pm 254$ \\
\hline $\mathrm{Co}$ & $58.2 \pm 33.4$ & $65.1 \pm 32.3$ & $80 \pm 50$ & $89 \pm 44$ & $65.2 \pm 27.2$ & $57.7 \pm 26.0$ & $112 \pm 53$ & $151 \pm 126$ \\
\hline $\mathrm{Cr}$ & $22 \pm 20$ & $31 \pm 21$ & $29 \pm 25$ & $94 \pm 42$ & $54 \pm 39$ & $8 \pm 9$ & $39 \pm 54$ & $18 \pm 24$ \\
\hline $\mathrm{Cu}$ & $11.3 \pm 7.1$ & $12.7 \pm 6.7$ & $27.3 \pm 28.4$ & $15 \pm 6$ & $12.7 \pm 5.3$ & $23.3 \pm 16.2$ & $19 \pm 8$ & $38.0 \pm 27.8$ \\
\hline $\mathrm{Nb}$ & $17.3 \pm 10.4$ & $16.3 \pm 10.7$ & $20.3 \pm 15.6$ & $33.2 \pm 14.6$ & $20.7 \pm 10.9$ & $11.7 \pm 4.9$ & $23.6 \pm 11.9$ & $69 \pm 37$ \\
\hline $\mathrm{Ni}$ & $13 \pm 6$ & $14 \pm 6$ & $18 \pm 9$ & $19 \pm 8$ & $14 \pm 4$ & $12 \pm 5$ & $21 \pm 9$ & $51 \pm 27$ \\
\hline $\mathrm{Pb}$ & $6.6 \pm 1.5$ & $6.1 \pm 1.4$ & $15.7 \pm 13.3$ & $6.3 \pm 1.2$ & $5.4 \pm 0.7$ & $27.3 \pm 19.1$ & $4.7 \pm 2.4$ & $5.5 \pm 3.1$ \\
\hline $\mathrm{Rb}$ & $44.9 \pm 17.7$ & $42.9 \pm 22.6$ & $75.7 \pm 45.5$ & $50.2 \pm 20.1$ & $39 \pm 17$ & $32 \pm 15$ & $54.4 \pm 17.8$ & $88.3 \pm 11.8$ \\
\hline $\mathrm{Sr}$ & $518 \pm 346$ & $541 \pm 426$ & $491 \pm 354$ & $291 \pm 118$ & $398 \pm 187$ & $662 \pm 149$ & $362 \pm 205$ & $236 \pm 206$ \\
\hline Th & $2.5 \pm 0.0$ & $2.5 \pm 0.0$ & $2.2 \pm 0.3$ & $3.1 \pm 0.8$ & $2.5 \pm 0.0$ & $2.8 \pm 0.3$ & $2.5 \pm 1.3$ & $3.8 \pm 1.9$ \\
\hline $\mathrm{V}$ & $9 \pm 4$ & $10 \pm 4$ & $14 \pm 7$ & $14 \pm 3$ & $11 \pm 6$ & $9 \pm 1$ & $11 \pm 6$ & $12 \pm 7$ \\
\hline $\mathrm{Y}$ & $21 \pm 12$ & $21 \pm 13$ & $26 \pm 17$ & $38 \pm 19$ & $22 \pm 11$ & $11 \pm 7$ & $28 \pm 11$ & $125 \pm 134$ \\
\hline $\mathrm{Zn}$ & $5.55 \pm 3.15$ & $3.72 \pm 3.39$ & $7.33 \pm 8.51$ & $11.9 \pm 6.3$ & $6.0 \pm 5.8$ & $60.7 \pm 68.1$ & $13.3 \pm 20.9$ & $6.17 \pm 7.75$ \\
\hline $\mathrm{Zr}$ & $419 \pm 389$ & $350 \pm 353$ & $89 \pm 14$ & $751 \pm 400$ & $440 \pm 326$ & $98 \pm 11$ & $347 \pm 356$ & $120 \pm 123$ \\
\hline
\end{tabular}

${ }^{1}$ Panuco River; ${ }^{2}$ Carrizal River; ${ }^{3}$ Soto La Marina River. 

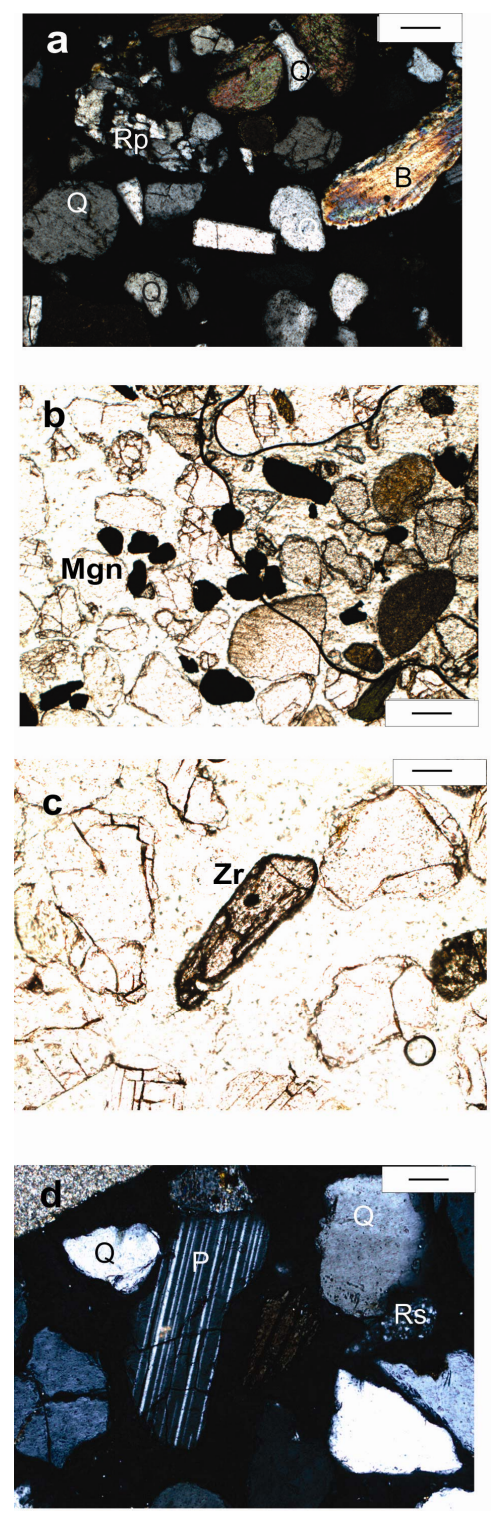

Figure 6. Photomicrographs of (a) $Q=$ subrounded, rounded and angular quartz grains, $R p=$ plutonic rock fragments, $B$ = shell fragments (sample 48a, Barra del Tordo beach sand); (b) magnetite grains (Mgn) in beach sands (sample 50, Barra del Tordo); (c) Zircon grain $(\mathrm{Zr})$ in beach sands (sample 50, Barra del Tordo); (d) $Q=$ rounded and angular quartz grains $\mathbf{P}=$ plagioclase, $\mathbf{R s}=$ sedimentary rock fragment (sandstone) (sample 11, Playa Miramar dune sands). Scale Bar is $\mathbf{5 0}$ microns.

the Cazones beach sands (Gulf of Mexico) but slightly away from the Northwestern Coast of Mexico beach sand samples based upon the work [10] that were used as a reference for compositional trends of the sands. In this study, most of the data overlaps and the separation between the beach, dune and river sands is not achieved. This is because the average major element values are not showing significant differences among the sand types due to their mobility.

\section{Discussion}

\subsection{Textural Parameters}

Negative correlations of grain size parameters in Playa Miramar (Figure 2(a)) and La Pesca (Figure 4(a)) beach sands between $\mathrm{Mz}(\varphi)$ and $\sigma(\varphi)$ may be due to a large range in mean grain size values since both beach sites have a wide coastal plain allowing a deposition of terrigenous sands but also to shell fragments that disperse the grain size values. In contrast, dune sands at Barra del Tordo are under a more selective process in the grain size characteristics allowing a more limited range in the grain size values in a narrow coastal plain (Figure 3). Correlations between $\mathrm{Mz} \phi$ and $\sigma \phi$ for the three sites are negative and highly significant as it has been observed in many beach and dune sand systems [2,7,27-31]. River sands showed significant negative correlations for $\mathrm{Mz}(\varphi)$ vs. $\sigma$ $(\varphi)$. However their negative correlations were observed at Carrizal River near Barra del Tordo beach and dune (Figure 3(a)) and Soto La Marina River sands near La Pesca site (Figure 4(a)), which are probably associated with the wide range of grain sizes observed in the beaches but not the dunes in Barra del Tordo associated with the presence of coarse shell fragments near the river mouth. Positive correlations between Mz $(\varphi)$ vs. Ski $(\varphi)$ were significant at Barra del Tordo beach, dune and river sands (Figure 3(b)) with symmetrical curves (i.e. mostly dune sands). However, some river and beach sands were coarse skewed indicating 1) long shore processes in a narrow coastal plain, which do not allow redistribution of fine-grained sands and 2) a narrow coastal plains close to river mouth discharging coarse sediments. The most significant correlation between $\mathrm{Mz}$ and $\mathrm{K}_{\mathrm{G}}$ indicate that Barra del Tordo dune sands and La Pesca beach sands are under the effect of winds and longshore currents respectively that are selective for the dune sands (i.e. Barra del Tordo) and redistributes the sediments in a wide coastal plain producing also platykurtic curves due to the presence of shell detritus (i.e. La Pesca).

\subsection{Modal Analysis}

The differences in mineralogic components have been observed in the Q-F-R ternary diagram (Figure 5). Playa Miramar, Barra del Tordo and La Pesca beach, dune and river sands are influenced by quartz-rich sands. Quartz enrichment is controlled by the input of sedimentary rocks mainly composed of sandstones and shales. This observation is supported by the amount of sedimentary lithics composed mainly by sandstones concentrated in the sands associated with a passive margin $[32,33]$.

The Panuco River concentrates slightly more quartzrich sands (94\%) compared to the Playa Miramar beach $(88 \%)$ and as much as the same percentage as the dune sands (90\%) (Figure 5(a)). The Playa Miramar beach 

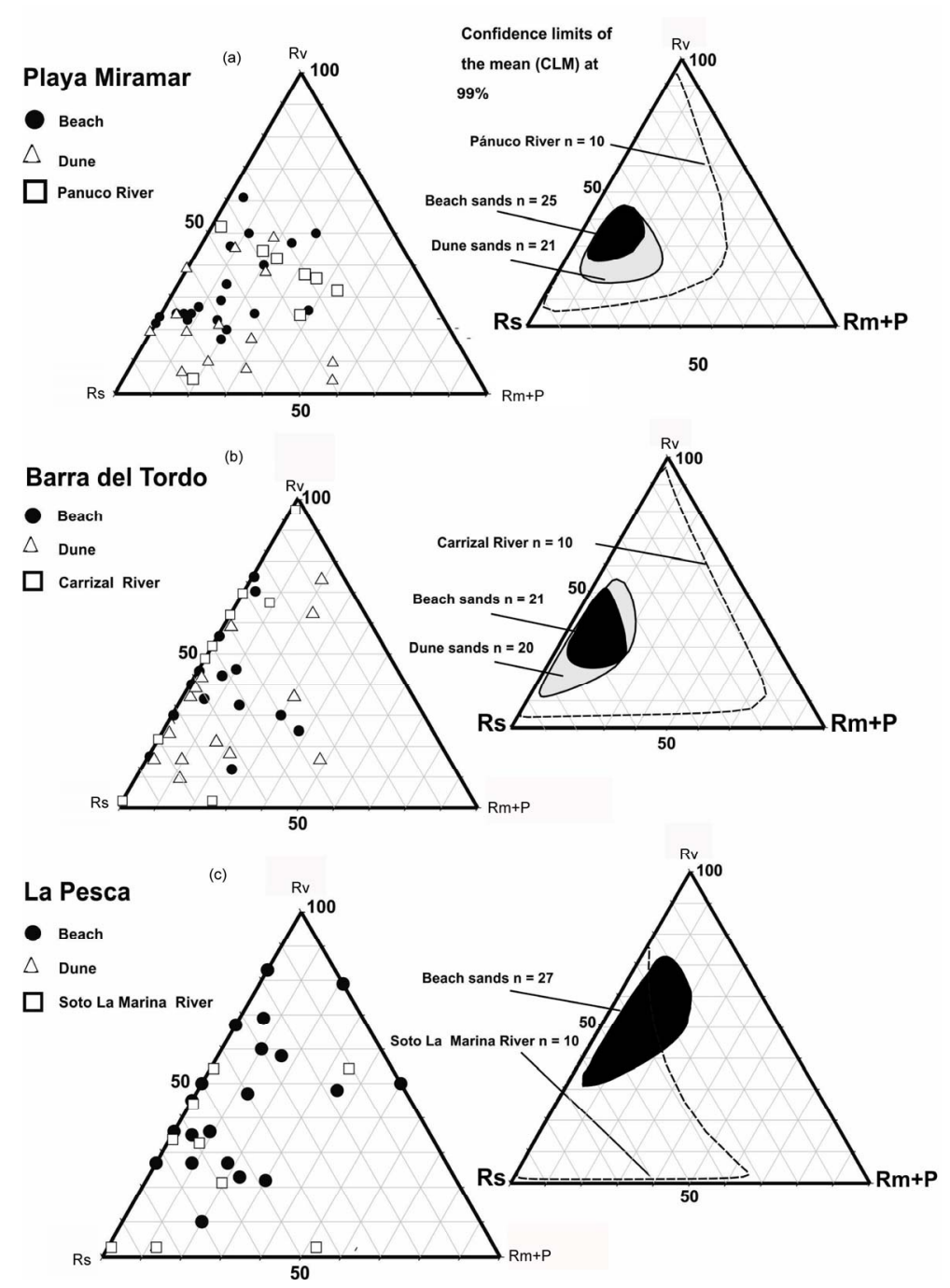

Figure 7. Rv - Rs - Rm+p ternary diagrams for (a) Playa Miramar, (b) Barra del Tordo and (c) La Pesca beach, dune and river sands with confidence limits of the mean (CLM) at $99 \%$ of confidence level (Weltje, 2002). Rv, volcanic lithic rock fragments; Rs, sedimentary lithic rock fragments; $R m$, metamorphic lithic rock fragments; $p$, plutonic lithic rock fragments; $n=$ number of samples.

and dune sands tend towards the $\mathrm{R}$ pole, which makes also a significant difference with the composition of the Panuco River sands. This observation is also supported by the lack of overlap among the beach, dune and river sands based upon the CLM area and the R percentages among the three sand types. This suggests that Playa Miramar beach and dune sands may be partially influenced by the Panuco River input as it is discussed in the forthcoming section.

The Barra del Tordo beach sands may be also not being influenced totally by the Carrizal River discharges since the CLM does not overlap with the CLM observed for the beach sands (Figure 5(b)). This suggests that the Carrizal Rivers is not contributing to the whole quartz fractions and probably to the $\mathrm{F}$ fraction to the Barra del Tordo beach sands and their concentrations may be con- trolled by the influence of other fluvial systems and/or redistributions of relict quartz fractions in the sands along the coast. High quartz concentrations in the river mouth may be also the part of the near shore processes and high energy that increases the quartz content in the sands.

La Pesca beach sands seem to have the similar composition as the Soto La Marina River sands since the CLM is overlapping for the beach and river sands (Figure 5(c)). In contrast to the study [34] in this case it has been observed that not always beach and dune sands tend to be close to the composition of nearby fluvial systems.

The $\mathrm{Rv}-\mathrm{Rs}-\mathrm{Rm}+\mathrm{p}$ ternary diagram (Figures 7(a) and (b)) shows that the Playa Miramar and Barra del Tordo beach and dune sands receive sedimentary and plutonic-metamorphic lithics derived from the Panuco and Carrizal Rivers since the CLM area overlaps on the 


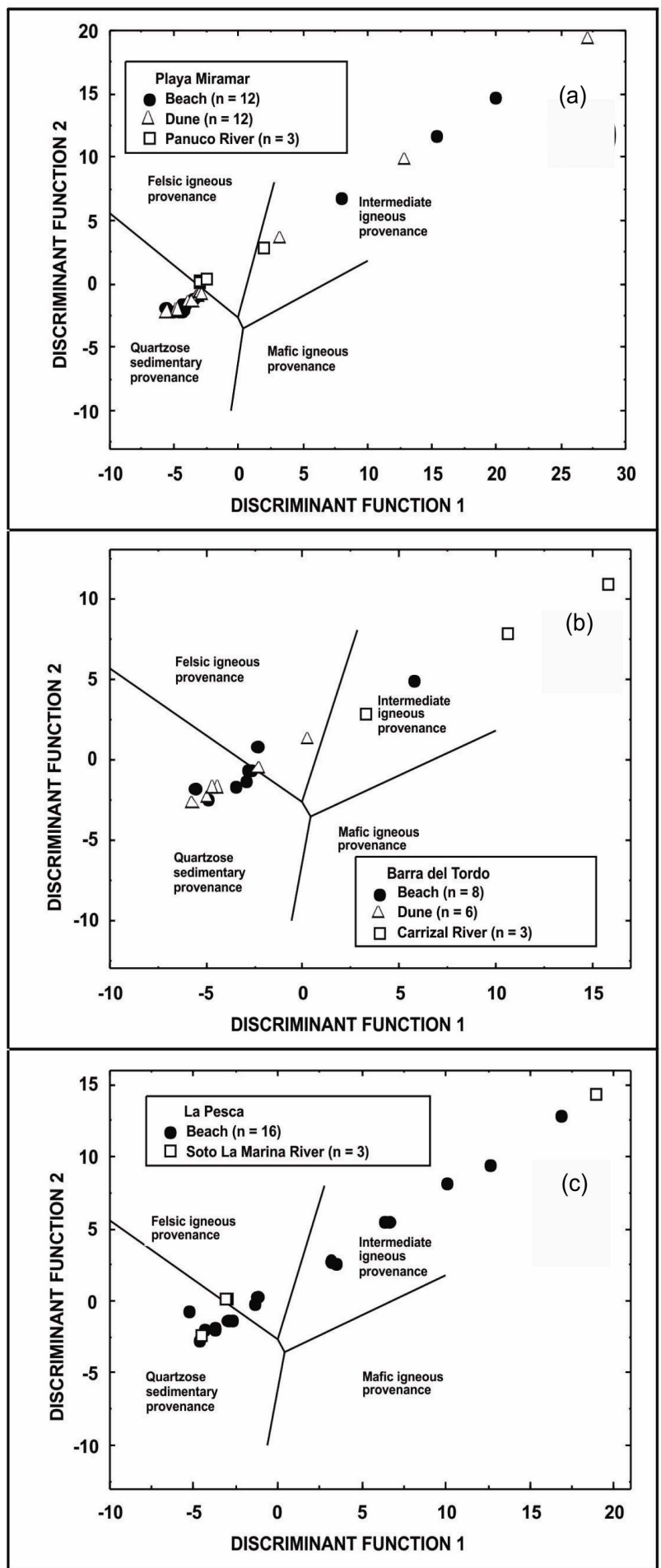

Figure 8. Provenance discrimination function diagram (Roser and Korsch 1988) for (a) Playa Miramar, (b) Barra del Tordo, (c) La Pesca beach, dune and river sands. The discriminant functions are: Discriminant Function $1=(-1.773$ $\left.\mathrm{TiO}_{2}\right)+\left(0.607 \mathrm{Al}_{2} \mathrm{O}_{3}\right)+\left(0.760 \mathrm{Fe}_{2} \mathrm{O}_{3}\right)+(-1.500 \mathrm{MgO})+$ $(0.616 \mathrm{CaO})+\left(0.509 \mathrm{Na}_{2} \mathrm{O}\right)+\left(-1.224 \mathrm{~K}_{2} \mathrm{O}\right)+(-9.090)$; Discriminant Function $2=\left(0.445 \mathrm{TiO}_{2}\right)+\left(0_{\left.0.070 \mathrm{Al}_{2} \mathrm{O}_{3}\right)+}+\right.$ $\left(-0.250 \mathrm{Fe}_{2} \mathrm{O}_{3}\right)+(-1.142 \mathrm{MgO})+(0.438 \mathrm{CaO})+\left(1.475 \mathrm{Na}_{2} \mathrm{O}\right)$ $+\left(-1.426 \mathrm{~K}_{2} \mathrm{O}\right)+(-6.861)$.

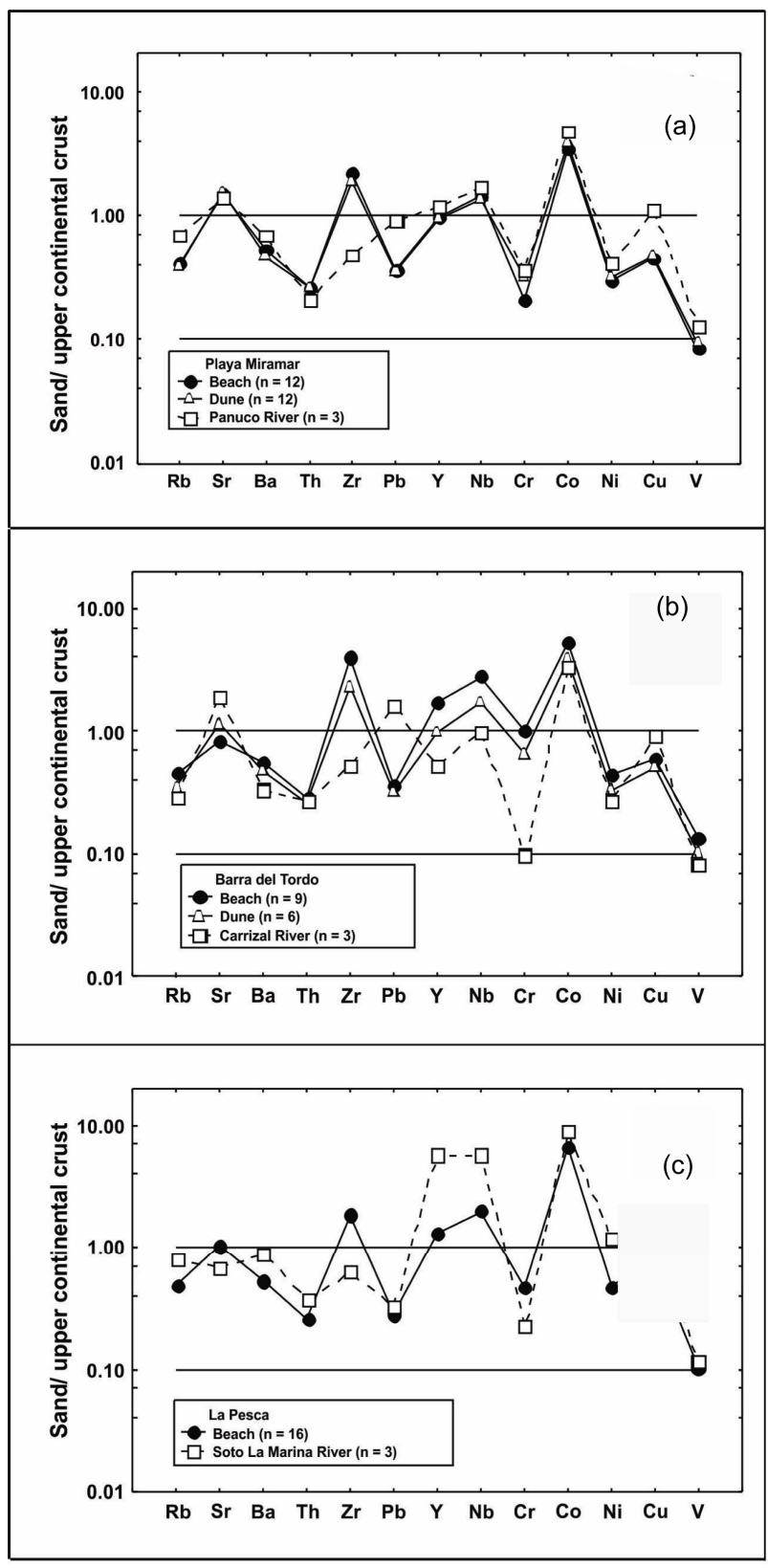

Figure 9. Multi-element normalized diagram for the (a) Playa Miramar, (b) Barra del Tordo and (c) La Pesca beach, dune and river sands, normalized against average upper continental crust.

three sand samples CLM region. The CLM of the Panuco and Carrizal River sands covers a larger area compared to the Miramar and Barra del Tordo sands and overlaps with the beach and dune sands CLM area suggesting that beach and dune sands may be under the influence of both rivers. Furthermore, it seems likely that Carrizal River is eroding volcanic outcrops (i.e. basalts) but the concentrations of these fractions are not reflected in the ternary diagram for the beach, dune and river sands probably due to high dispersion in the $\mathrm{Rv}-\mathrm{Rs}-\mathrm{Rm}+\mathrm{p}$ composi- 
Table 4. Average rare earth elements data (ppm) for the beach, dune, and river sands of the northwestern Gulf of Mexico.

\begin{tabular}{|c|c|c|c|c|c|c|c|c|}
\hline & \multicolumn{3}{|c|}{ Playa Miramar } & \multicolumn{3}{|c|}{ Barra del Tordo } & \multicolumn{2}{|c|}{ La Pesca } \\
\hline & $\begin{array}{l}\text { Beach } \\
(n=8)\end{array}$ & $\begin{array}{l}\text { Dune } \\
(n=6)\end{array}$ & $\begin{array}{l}\text { River }^{1} \\
(\mathrm{n}=3)\end{array}$ & $\begin{array}{c}\text { Beach } \\
(n=12)\end{array}$ & $\begin{array}{l}\text { Dune } \\
(n=4)\end{array}$ & $\begin{array}{l}\text { River }^{2} \\
(\mathrm{n}=3)\end{array}$ & $\begin{array}{l}\text { Beach } \\
(n=8)\end{array}$ & $\begin{array}{l}\text { River }^{3} \\
(\mathrm{n}=3)\end{array}$ \\
\hline $\mathrm{La}$ & $12.5 \pm 4.8$ & $13.6 \pm 8.2$ & $10.3 \pm 0.9$ & $13.0 \pm 6.0$ & $13.8 \pm 4.3$ & $8.3 \pm 1.2$ & $7.74 \pm 1.33$ & $9.00 \pm 2.12$ \\
\hline $\mathrm{Ce}$ & $22.2 \pm 9.3$ & $24.9 \pm 15.7$ & $18.0 \pm 1.1$ & $24.6 \pm 13.1$ & $25.3 \pm 7.2$ & $14.2 \pm 1.7$ & $13.5 \pm 2.9$ & $15.5 \pm 3.3$ \\
\hline $\operatorname{Pr}$ & $2.73 \pm 0.95$ & $3.11 \pm 1.84$ & $2.28 \pm 0.23$ & $3.07 \pm 1.57$ & $3.13 \pm 0.81$ & $1.85 \pm 0.25$ & $1.74 \pm 0.32$ & $2.03 \pm 0.43$ \\
\hline $\mathrm{Nd}$ & $10.2 \pm 3.3$ & $11.7 \pm 6.8$ & $8.42 \pm 0.84$ & $11.5 \pm 6.0$ & $11.6 \pm 2.8$ & $7.01 \pm 0.89$ & $6.39 \pm 1.29$ & $7.53 \pm 1.52$ \\
\hline $\mathrm{Sm}$ & $1.98 \pm 0.50$ & $2.33 \pm 1.27$ & $1.65 \pm 0.17$ & $2.14 \pm 1.13$ & $2.14 \pm 0.46$ & $1.37 \pm 0.20$ & $1.25 \pm 0.24$ & $1.49 \pm 0.36$ \\
\hline $\mathrm{Eu}$ & $0.87 \pm 0.19$ & $0.93 \pm 0.15$ & $0.83 \pm 0.29$ & $0.74 \pm 0.16$ & $0.75 \pm 0.09$ & $0.61 \pm 0.22$ & $0.54 \pm 0.08$ & $0.76 \pm 0.31$ \\
\hline Gd & $1.77 \pm 0.44$ & $2.11 \pm 1.28$ & $1.49 \pm 0.11$ & $1.88 \pm 0.96$ & $1.96 \pm 0.52$ & $1.23 \pm 0.15$ & $1.09 \pm 0.22$ & $1.35 \pm 0.25$ \\
\hline $\mathrm{Tb}$ & $0.25 \pm 0.07$ & $0.30 \pm 0.15$ & $0.20 \pm 0.02$ & $0.27 \pm 0.15$ & $0.26 \pm 0.06$ & $0.16 \pm 0.02$ & $0.16 \pm 0.03$ & $0.19 \pm 0.05$ \\
\hline Dy & $1.46 \pm 0.38$ & $1.79 \pm 0.97$ & $1.18 \pm 0.11$ & $1.59 \pm 0.91$ & $1.63 \pm 0.41$ & $0.95 \pm 0.17$ & $0.92 \pm 0.18$ & $1.11 \pm 0.25$ \\
\hline Ho & $0.31 \pm 0.08$ & $0.36 \pm 0.19$ & $0.25 \pm 0.04$ & $0.34 \pm 0.21$ & $0.34 \pm 0.07$ & $0.19 \pm 0.04$ & $0.19 \pm 0.03$ & $0.23 \pm 0.06$ \\
\hline $\mathrm{Er}$ & $0.75 \pm 0.23$ & $0.93 \pm 0.49$ & $0.66 \pm 0.04$ & $0.85 \pm 0.52$ & $0.87 \pm 0.22$ & $0.47 \pm 0.07$ & $0.47 \pm 0.08$ & $0.60 \pm 0.13$ \\
\hline $\mathrm{Tm}$ & $0.12 \pm 0.04$ & $0.15 \pm 0.08$ & $0.10 \pm 0.02$ & $0.13 \pm 0.08$ & $0.14 \pm 0.03$ & $0.07 \pm 0.02$ & $0.07 \pm 0.01$ & $0.09 \pm 0.03$ \\
\hline $\mathrm{Yb}$ & $0.82 \pm 0.29$ & $0.98 \pm 0.59$ & $0.68 \pm 0.10$ & $0.93 \pm 0.61$ & $0.98 \pm 0.28$ & $0.46 \pm 0.12$ & $0.47 \pm 0.09$ & $0.58 \pm 0.13$ \\
\hline $\mathrm{Lu}$ & $0.14 \pm 0.06$ & $0.17 \pm 0.10$ & $0.11 \pm 0.03$ & $0.16 \pm 0.10$ & $0.17 \pm 0.04$ & $0.07 \pm 0.02$ & $0.08 \pm 0.02$ & $0.10 \pm 0.03$ \\
\hline$\sum \mathrm{REE}$ & $56 \pm 20$ & $63 \pm 37$ & $46 \pm 3$ & $61 \pm 31$ & $63 \pm 17$ & $37 \pm 5$ & $35 \pm 7$ & $40 \pm 9$ \\
\hline
\end{tabular}

${ }^{1}$ Panuco River; ${ }^{2}$ Carrizal River; ${ }^{3}$ Soto La Marina River.

Table 5. Average elemental ratios for the beach, dune, and river sands of the northwestern Gulf of Mexico.

\begin{tabular}{|c|c|c|c|c|c|c|c|c|}
\hline & \multicolumn{3}{|c|}{ Playa Miramar } & \multicolumn{3}{|c|}{ Barra del Tordo } & \multicolumn{2}{|c|}{ La Pesca } \\
\hline & $\begin{array}{l}\text { Beach } \\
(n=8)\end{array}$ & $\begin{array}{c}\text { Dune } \\
(\mathrm{n}=6)\end{array}$ & $\begin{array}{l}\text { River }^{1} \\
(\mathrm{n}=3)\end{array}$ & $\begin{array}{c}\text { Beach } \\
(n=12)\end{array}$ & $\begin{array}{l}\text { Dune } \\
(n=4)\end{array}$ & $\begin{array}{l}\text { River }^{2} \\
(\mathrm{n}=3)\end{array}$ & $\begin{array}{l}\text { Beach } \\
(\mathrm{n}=8)\end{array}$ & $\begin{array}{l}\text { River }^{3} \\
(\mathrm{n}=3)\end{array}$ \\
\hline $\mathrm{Eu} / \mathrm{Eu}^{*}$ & $1.43 \pm 0.33$ & $1.43 \pm 0.40$ & $1.56 \pm 0.43$ & $1.27 \pm 0.40$ & $1.13 \pm 0.15$ & $1.40 \pm 0.93$ & $1.42 \pm 0.24$ & $1.56 \pm 0.41$ \\
\hline$(\mathrm{La} / \mathrm{Lu})_{\mathrm{cn}}$ & $10.4 \pm 1.86$ & $9.37 \pm 0.95$ & $10.3 \pm 1.31$ & $10.5 \pm 2.05$ & $7.58 \pm 1.47$ & $12.3 \pm 1.62$ & $11.3 \pm 1.13$ & $10.4 \pm 0.66$ \\
\hline$(\mathrm{Gd} / \mathrm{Yb})_{\mathrm{cn}}$ & $1.79 \pm 0.18$ & $1.75 \pm 0.11$ & $1.80 \pm 0.28$ & $1.78 \pm 0.31$ & $1.65 \pm 0.22$ & $2.20 \pm 0.40$ & $1.87 \pm 0.14$ & $1.89 \pm 0.07$ \\
\hline $\begin{array}{l}\text { LREE/ } \\
\text { HREE }\end{array}$ & $8.72 \pm 1.02$ & $8.10 \pm 0.64$ & $8.70 \pm 0.34$ & $9.12 \pm 0.92$ & $8.83 \pm 0.87$ & $9.13 \pm 0.39$ & $8.85 \pm 0.29$ & $8.37 \pm 0.25$ \\
\hline $\mathrm{Th} / \mathrm{Co}^{4}$ & $0.07 \pm 0.06$ & $0.07 \pm 0.07$ & $0.04 \pm 0.04$ & $0.06 \pm 0.07$ & $0.05 \pm 0.02$ & $0.06 \pm 0.02$ & $1.25 \pm 0.24$ & $1.49 \pm 0.36$ \\
\hline $\mathrm{Th} / \mathrm{Cr}^{4}$ & $0.77 \pm 0.73$ & $0.50 \pm 0.66$ & $0.11 \pm 0.08$ & $0.20 \pm 0.49$ & $0.09 \pm 0.06$ & $0.81 \pm 0.77$ & $0.54 \pm 0.08$ & $0.76 \pm 0.31$ \\
\hline
\end{tabular}

Subscript ${ }_{\mathrm{cn}}$ refers to chondrite normalized ratio (Taylor and McLennan 1985). ${ }^{1}$ Panuco River; ${ }^{2}$ Carrizal River; ${ }^{3}$ Soto La Marina River; ${ }^{4}$ Refer Table 4 for number of samples (n).

tional data in the river and due to less number of samples that increases the shape of the CLM area for the Carrizal River. Volcanic lithics influence is taking place at $\mathrm{La}$ Pesca beach sands but the Soto La Marina River sands are low in volcanic lithics content (Table 2), which suggests a partial contribution of the Soto La Marina River sands to the composition of the La Pesca beach sands. This is also supported by the CLM shape (Figure 7(c)).

High HM content in the Barra del Tordo beach and dune sands is composed of magnetite grains in the finesized fractions $(2.25 \varphi-2.30 \varphi)$. Magnetite is probably derived from the sedimentary terranes exposed along the coast (i.e. shales and sandstones). The Carrizal River is depleted in HM which may suggests that magnetite grains in the beach and dune sands are probably a remnant of past fluvial discharges and/or redistribution/deflation and winnowing of sediments along the coast. This is also sup- ported by the fact that average grain-size in the Carrizal River is $1.93 \varphi$ (i.e. medium-sized fractions) and the dunes show fine sized fractions $(2.22 \varphi)$ (Figure 3(a) and Table 2) which suggests concentration of heavy minerals in the finer fractions defining the source rock [35-37]. Also, deflation/winnowing of lighter minerals due to the wind action which takes place in the beach and dune environments leaves the "heavies" in the uppermost sand cover. The river action is also incapable of disaggregate rock fragments into their monomineralic components under short distances seawards (i.e. Carrizal River). This observation is also supported by the area cover by the CLM in the rock fragments diagram for river sand samples compared to the rest of the sedimentary environments studied suggesting a prevail preservation of rock fragments in the fluvial sands and the lack of fine-sand fractions with heavy minerals (Figures 3(a) and 7). 


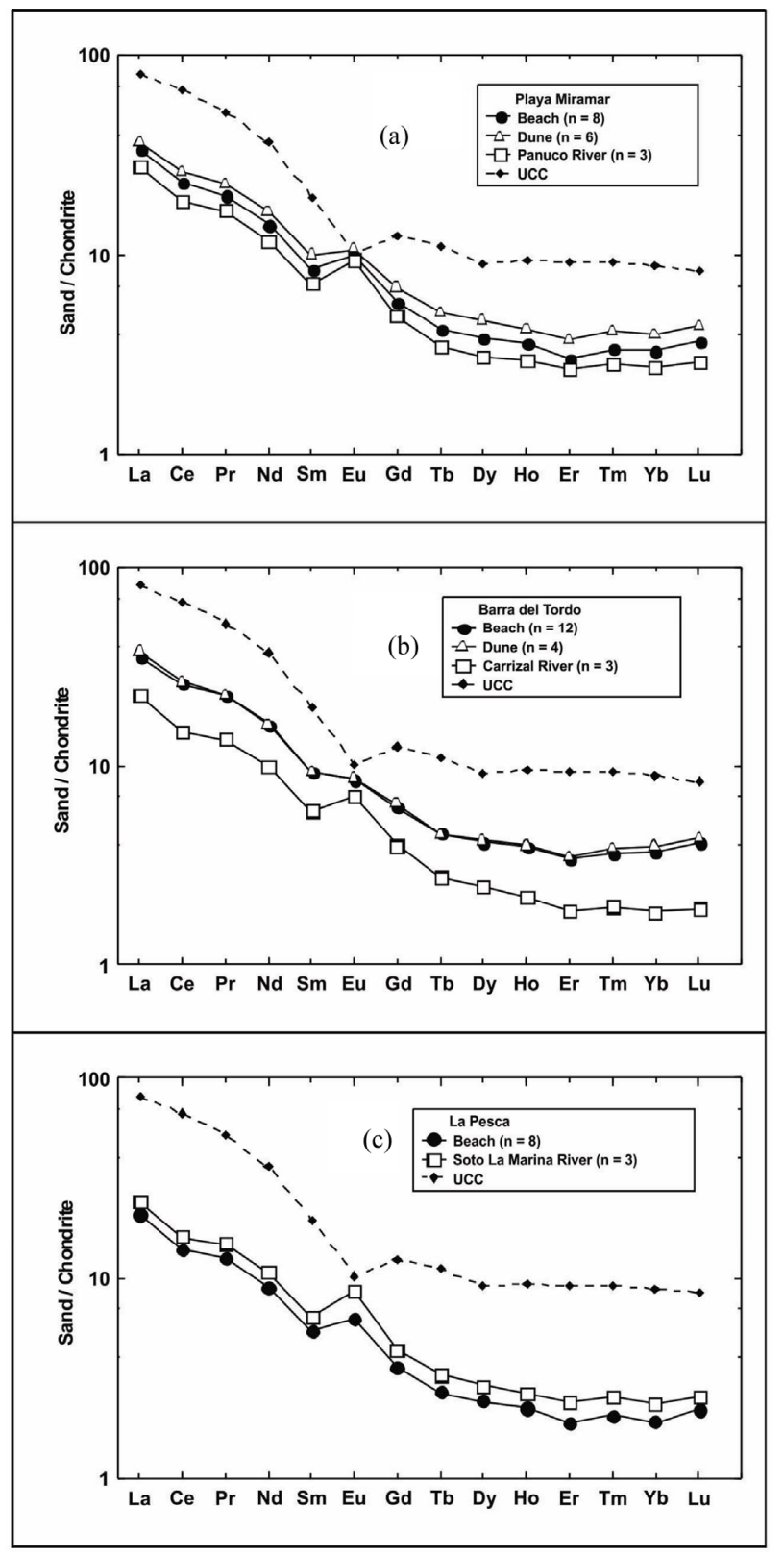

Figure 10. Average chondrite normalized REE patterns for (a) Playa Miramar, (b) Barra del Tordo, and (c) La Pesca beach, dune and river sands.

The high content of the $\mathrm{B}$ fraction in the three sedimentary environments (i.e. beach, dune, river) is observed due to the presence of shell fragments. However, the high content of B in the river sands is due to the fact that samples were collected at the river mouth close to the beach (Table 2).

\subsection{Geochemistry}

The Barra del Tordo dune sands show the highest average values of $\mathrm{TiO}_{2}, \mathrm{Fe}_{2} \mathrm{O}_{3}$ and $\mathrm{MgO}$ compared to the rest of the sites (Table 3). This suggests that some Barra del-

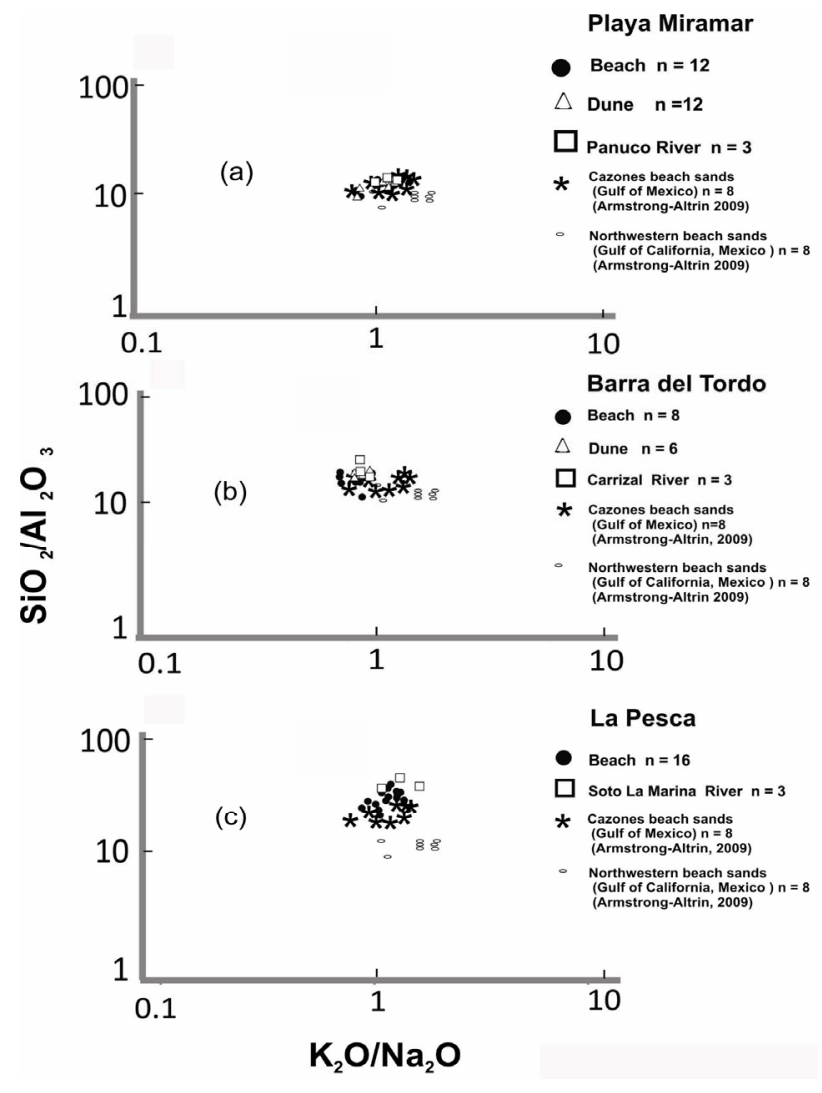

Figure 11. $\mathrm{K}_{2} \mathrm{O} / \mathrm{Na}_{2} \mathrm{O}-\mathrm{SiO}_{2} / \mathrm{Al}_{2} \mathrm{O}_{3}$ bivariate diagram for the beach, dune and river sands of (a) Playa Miramar, (b) Barra del Tordo and (c) La Pesca. Data for comparison are from $[10]$.

tordo beach and dune sands are influenced by mafic minerals as it has been reported in beaches from the southern Gulf of Mexico in which the volcanic input comes from the TMVB (Trans Mexican Volcanic Belt; [29]). Furthermore, it has been observed a moderate to low ratio of $\mathrm{TiO}_{2} / \mathrm{Fe}_{2} \mathrm{O}_{3}$ in the beach $(0.53 \pm 0.23)$ and dune sands $(0.58 \pm 0.18)$ of Barra del Tordo that is related to the presence of magnetite with low $\mathrm{TiO}_{2}$ content $[38,39]$ and with depletion of opaque minerals in the Carrizal River sands. Also, it is likely that the higher values of $\mathrm{MgO}$ observed in the Barra del Tordo beach and dune sands (Table 6) compared to the rest of the sites suggests the accumulation of magnetite in the sands as $\mathrm{MgO}$ is a good discriminator of magnetite grains from different rock sources and indicates a recycled orogeny provenance $[40,41]$. Provenance studies of sandstone formations (i.e. Karharbari, India) results agree with the recycled orogeny provenance like in the Barra del Tordo beach and dune sands associated to sandstone outcrops exposed near the coast [42]. This suggests that magnetite fractions in the Barra del Tordo beach and dune sands are probably not related to the Carrizal River sands input seawards but to another alternative fluvial sources and/or long shore processes, deflation of light minerals and 
Table 6. Average major elements data (\%) for the beach, dune, and river sands of the northwestern Gulf of Mexico.

\begin{tabular}{ccccccccc}
\hline \multicolumn{3}{c}{ Playa Miramar } & \multicolumn{3}{c}{ Barra del Tordo } \\
\hline & $\begin{array}{c}\text { Beach } \\
(\mathrm{n}=12)\end{array}$ & $\begin{array}{c}\text { Dune } \\
(\mathrm{n}=12)\end{array}$ & $\begin{array}{c}\text { River }^{1} \\
(\mathrm{n}=3)\end{array}$ & $\begin{array}{c}\text { Beach } \\
(\mathrm{n}=8)\end{array}$ & $\begin{array}{c}\text { Dune } \\
(\mathrm{n}=6)\end{array}$ & $\begin{array}{c}\text { River }^{2} \\
(\mathrm{n}=3)\end{array}$ & $\begin{array}{c}\text { Beach }^{2} \\
(\mathrm{n}=16)\end{array}$ & $\begin{array}{c}\text { River }^{3} \\
(\mathrm{n}=3)\end{array}$ \\
\hline $\mathrm{SiO}_{2}$ & $75 \pm 18$ & $74 \pm 18$ & $77 \pm 6$ & $78 \pm 8$ & $81 \pm 4$ & $56 \pm 12$ & $71 \pm 14$ & $69 \pm 27$ \\
$\mathrm{TiO}_{2}$ & $0.46 \pm 0.57$ & $0.47 \pm 0.38$ & $0.08 \pm 0.01$ & $0.82 \pm 0.73$ & $0.92 \pm 0.64$ & $0.12 \pm 0.04$ & $0.31 \pm 0.73$ & $0.12 \pm 0.08$ \\
$\mathrm{Al}_{2} \mathrm{O}_{3}$ & $3.65 \pm 0.62$ & $3.53 \pm 0.79$ & $4.74 \pm 0.28$ & $3.83 \pm 0.81$ & $3.74 \pm 0.27$ & $2.84 \pm 1.19$ & $3.19 \pm 0.47$ & $3.86 \pm 0.98$ \\
$\mathrm{Fe}_{2} \mathrm{O}_{3}$ & $0.83 \pm 0.66$ & $0.86 \pm 0.44$ & $0.49 \pm 0.01$ & $1.29 \pm 0.84$ & $1.42 \pm 0.83$ & $1.04 \pm 0.15$ & $0.61 \pm 0.81$ & $0.51 \pm 0.05$ \\
$\mathrm{MnO}$ & $0.04 \pm 0.02$ & $0.04 \pm 0.01$ & $0.02 \pm 0.01$ & $0.06 \pm 0.03$ & $0.06 \pm 0.02$ & $0.04 \pm 0.01$ & $0.04 \pm 0.02$ & $0.02 \pm 0.02$ \\
$\mathrm{MgO}$ & $0.27 \pm 0.10$ & $0.27 \pm 0.06$ & $0.25 \pm 0.05$ & $0.31 \pm 0.11$ & $0.32 \pm 0.09$ & $0.25 \pm 0.07$ & $0.21 \pm 0.09$ & $0.23 \pm 0.16$ \\
$\mathrm{CaO}$ & $10 \pm 10$ & $11 \pm 10$ & $8.01 \pm 3.77$ & $7.62 \pm 4.86$ & $6.21 \pm 2.68$ & $22 \pm 7$ & $13 \pm 8$ & $13 \pm 15$ \\
$\mathrm{Na} 2 \mathrm{O}$ & $0.86 \pm 0.09$ & $0.85 \pm 0.12$ & $1.15 \pm 0.11$ & $0.89 \pm 0.26$ & $0.84 \pm 0.10$ & $0.79 \pm 0.18$ & $0.8 \pm 0.1$ & $1.00 \pm 0.22$ \\
$\mathrm{~K}_{2} \mathrm{O}$ & $1.09 \pm 0.18$ & $1.05 \pm 0.25$ & $1.68 \pm 0.26$ & $1.04 \pm 0.39$ & $0.99 \pm 0.11$ & $0.85 \pm 0.29$ & $0.93 \pm 0.16$ & $1.28 \pm 0.51$ \\
$\mathrm{P}_{2} \mathrm{O}_{5}$ & $0.03 \pm 0.00$ & $0.03 \pm 0.01$ & $0.03 \pm 0.02$ & $0.03 \pm 0.01$ & $0.03 \pm 0.01$ & $0.08 \pm 0.02$ & $0.03 \pm 0.01$ & $0.03 \pm 0.01$ \\
$\mathrm{LOI}$ & $8.02 \pm 8.00$ & $8.35 \pm 8.00$ & $6.24 \pm 3.02$ & $5.76 \pm 3.89$ & $4.62 \pm 2.35$ & $17 \pm 6$ & $10 \pm 7$ & $10 \pm 8$ \\
$\mathrm{Total}$ & $100 \pm 0.59$ & $100 \pm 0.69$ & $100 \pm 0.37$ & $100 \pm 0.60$ & $100 \pm 0.66$ & $100 \pm 0.76$ & $100 \pm 0.47$ & $100 \pm 0.35$ \\
\hline
\end{tabular}

$\mathrm{LOI}=$ loss of ignition, $\mathrm{CaO}=$ values obtained with shell fragment content in the whole bulk composition of the sands. ${ }^{1}$ Panuco River; ${ }^{2} \mathrm{Carrizal}$ River; ${ }^{3}$ Soto La Marina River.

re-distribution of magnetite fractions along the coast.

\subsubsection{Major Geochemical Provinces}

The provenance discriminant function diagrams [26] (Figures 8(a)-(c)) shows that the Carrizal River sand composition is placed in the intermediate igneous province, whereas their beach and dune counterparts are placed mainly in the quartzose sedimentary province probably due to recycled episodes in the sands that do not reflect the real source rock that influences the composition of the beach and dune sands (Figure 8(b)). Discriminant coefficients show that $\mathrm{TiO}_{2}(-1.773), \mathrm{MgO}(-1.500)$, $\mathrm{Fe}_{2} \mathrm{O}_{3}(0.760)$ and $\mathrm{K}_{2} \mathrm{O}(-1.224)$ are the elements that control the separation of the Carrizal River sands from the Barra del Tordo beach and dune sands. This indicates that the Carrizal River sands excerts little compositional control in the Barra del Tordo beach and dune sands associated with the presence/depletion of magnetite. Also, the Carrizal River sands placed in the intermediate igneous province is related more to the low $\mathrm{K}_{2} \mathrm{O}$ content in the river sands compared to the Barra del Tordo beach and dune sands rather than the main source rock controlling the composition of the sands. These geochemical results support the petrographic analysis based upon the $\mathrm{Q}-\mathrm{F}-\mathrm{R}$ and $\mathrm{Rv}-\mathrm{Rs}-\mathrm{Rm}+\mathrm{p}$ ternary diagrams (Figures 5 and 7), respectively.

\subsubsection{Trace Element Signatures}

Upper continental crust (UCC) normalized trace elements show that the trends for Playa Miramar, Barra del Tordo and La Pesca sites are similar with the exception of some samples containing higher concentration of $\mathrm{Sr}$ in the Carrizal River at Barra del Tordo compared to the rest of the sites (Figure 9(a)). This high concentration of
$\mathrm{Sr}$ in the Carrizal River sands is associated with the depletion of $\mathrm{Ba}$, which co-exists in many types of sediment and indicates the low content of $\mathrm{K}$ feldspars in the sands [43]. This observation is also supported by the low average values of potash feldspar (Fk), $\mathrm{K}_{2} \mathrm{O}$ and $\mathrm{Ba}$ in the Carrizal River sands. The $\mathrm{P} / \mathrm{K}$ ratio for the Carrizal River and Barra del Tordo dune sands are $1.80( \pm 2.27)$ and $1.88( \pm 2.84)$, respectively that are related to the "peak" of Sr content in both sands.

The high concentration of $\mathrm{Zr}$ for the three beach and dune sites suggest the presence of heavy minerals like zircon probably derived from sandstones well exposed along the coast and from granitic rocks [11,44] (Figure 6(c)). However, the Panuco, Carrizal and Soto La Marina River sands have less concentration of $\mathrm{Zr}$, which suggests that river sands are not contributing to the presence of $\mathrm{Zr}$ in the beach and dune sands at Barra del Tordo. However, since zircon is present as a free fraction in finer grain sizes i.e. $\sim 3.25 \varphi-4.0 \varphi$ [45] than those observed for the present study, it is likely that $\mathrm{Zr}$ is present as part of the petrologic framework of the sediments probably included in sandstones and/or plutonic rock fragments in the beach and dune sands [46]. However, some free zircon crystals were observed at Barra del Tordo beach sands suggesting disaggregation of rock fragments into their monomineralic components like zircon (Figure 6(c)).

The high concentrations of UCC normalized $\mathrm{Y}$ and $\mathrm{Nb}$ for the beach, dune and river sands at Playa Miramar and La Pesca sites (Figure 9(a)) can be attributed to the enrichment in the light REE relative to heavy REE but also indicate the contribution of sands from felsic sources, especially in the Panuco and Soto la Marina Rivers [47]. Also, the Panuco and Soto La Marina River sands exhibit 
the highest $\mathrm{K}_{2} \mathrm{O}$ concentrations (Table 6), which makes the $\mathrm{Nb}$ values increase [48]. However, the enrichment of $\mathrm{Y}$ and $\mathrm{Nb}$ contents in the Soto La Marina River sands is due to the combination of the increase in the LREE concentration and/or the high amount of quartz in the sands, which is supported by the quartz percentage (96\%) and the $\mathrm{K}_{2} \mathrm{O}$ content in the river sands (Table 6).

High Co concentrations in the beach, dune and river sands may be due the presence of some basaltic rock fragments and/or sedimentary lithics especially shales that contain Co $(\sim 17-19 \mathrm{ppm})[49,50]$. The depletion of $\mathrm{Cr}$ in the Playa Miramar and La Pesca sites is probably associated with the low concentration of heavy minerals [51].

$\mathrm{Cr}$ and $\mathrm{Ni}$ are only highly correlated for the Miramar dune sands $(\mathrm{r}=0.82)$ with an average $\mathrm{Cr} / \mathrm{Ni}$ ratio of 1.79 ( $\mathrm{Std} \mathrm{dev}=3.42$ ). The $\mathrm{Cr} / \mathrm{Ni}$ ratio value are comparable to those observed for grey shales $(\sim 1.16-5.16)$ and it is indicative of felsic sources [52]. In contrast, high concentrations of $\mathrm{Cr}$ in the Barra del Tordo beach and dune sands with low correlation coefficient values $(r=0.49 ; r$ $=-0.17$, respectively) suggest the presence of more intermediate to mafic bearing minerals like magnetite and $\mathrm{Cr}$ content associated with impurities in the magnetite crystals. The Carrizal River sands shows the lowest concentration of $\mathrm{Cr}$ values compared to other sites including Barra del Tordo beach and dune sands, which is probably a consequence of the depletion of magnetite grain in the sands [51].

Depletion of Th, Ba, Ni and V in the sands of the three sites is related to felsic sources as indicated by the $\mathrm{Th} / \mathrm{Co}$ and $\mathrm{Th} / \mathrm{Cr}$ ratios with some andesitic fractions present as part of the compositional framework of Barra del Tordo and La Pesca beach and dune sands [53,54] (Table 5).

\subsubsection{Rare Earth Elements Trend}

The REE patterns of the beach, dune and river sands show a slight depletion of HREE compared to the LREE concentrations suggesting a mixing of felsic and intermediate sources in the composition of the beach and dune sands for the three sites as it is also observed by the Eu positive anomaly $[9,55,56]$. The Panuco and Carrizal Rivers show lower concentrations of $\Sigma$ REE compared to the Playa Miramar and Barra del Tordo beach and dune sands (Table 4). The Soto La Marina shows higher REE concentration compared to the La Pesca beach sands. Rivers in general seem to be controlling just in part the REE geochemical signals of the beach and dune sands from the three sites. This can be clearly observed in the Carrizal River sands that are depleted in REE compared to the Barra del Tordo beach and dune sands (Table 4), suggesting a fractionation process during the fluvial sand transport seawards that diminishes the concentration of potential REE carriers (i.e. hornblende, sphene, titano-magnetite) [57]. Fractionation of heavy minerals controls the high and/or low concentration of REE during transport, mechanical abrasion of the heavy minerals and chemical weathering $[9,33]$.

It is also observed that the beach, dune and river sands from the three sites have a Eu positive anomaly (Table 5) that is related to $\mathrm{P} / \mathrm{K}$ ratios between 0.35 and 2.13 that increases the Eu positive anomaly (Figure 6(d); Table 2). It is likely that the Eu positive anomaly for the three sites are linked to the presence of intermediate rocks like granodiorites and andesites that contain plagioclase as monomineralic components that are not disgregated during the transport [46] (Figure 1). Additionally, it is likely that the Eu positive anomaly is related to the relatively low chemical index of alteration values of the sands CIA $=\left[\mathrm{Al}_{2} \mathrm{O}_{3} /\left(\mathrm{Al}_{2} \mathrm{O}_{3}+\mathrm{CaO}^{*}+\mathrm{Na}_{2} \mathrm{O}+\mathrm{K}_{2} \mathrm{O}\right)\right] \times 100$ [58] for the three sites between 52 and 63 keeping "unaltered" sands under a long time despite the humid conditions. In some areas like Papua New Guinea deltas remain chemically unaltered despite the humid conditions and deltaderived sediments reach the coast without high rates of weathering [59]. Also the Eu positive anomalies have been observed in weathered minerals (i.e. magnetite) forming goethite in oxidizing conditions in marshes [60] although this statement can only be supported partially with the presence of magnetite as an accessory heavy mineral in the beach and dune sands at Barra del Tordo.

The $(\mathrm{La} / \mathrm{Lu})_{\mathrm{cn}}$ ratio for the whole sands ranges from 6.86 to 9.83 , which are similar to the values observed for the quartz rich felsic beach sands $\left(\mathrm{La}_{\mathrm{cn}} / \mathrm{Lu}_{\mathrm{cn}}=7.87 \pm\right.$ 1.56); $\mathrm{n}=16$ [10] and quartz arenites [61]. However, the Panuco and Carrizal River sands have the highest $(\mathrm{La} / \mathrm{Lu})_{\mathrm{cn}}$ ratio (Table 5), indicating the quartz enrichment in the river sands compare to their beach and dune sands counterparts.

The $(\mathrm{Gd} / \mathrm{Yb})_{\mathrm{cn}}$ ratio is $>2$ for the the Carrizal River sands suggests that river sands are depleted in HREE concentrations compared to their beach and dune sands counterparts suggesting less input of heavy minerals as potential carriers of HREE seawards and volcanic sources influencing its composition $[37,62]$.

\subsection{4. $\mathrm{SiO}_{2} / \mathrm{Al}_{2} \mathrm{O}_{3}$ versus $\mathrm{K}_{2} \mathrm{O} / \mathrm{Na}_{2} \mathrm{O}$ Plot}

The Cazones beach sands seem to be chemically related to the sands of this study suggesting the possible felsic and andesitic source rocks controlling their composition. In the case of the Northwestern Coast beach sands it seems that their composition is more due to the granite sources rather than a mix of felsic and intermediate source like the sands of this study. The average $\mathrm{SiO}_{2} / \mathrm{Al}_{2} \mathrm{O}_{3}$ ratios for the beach, dune and river sands at the three sites ( $\sim 16.2$ to 22.3 ) show that the sands have experienced textural maturity and depletion of phyllosilicates $[16,37]$. 


\section{Conclusions}

1) A large range of grain-sizes was observed for the Playa Miramar and La Pesca beach sands since both sites had a wide coastal plain allowing the deposition of terrigenous sands but also to shell fragments that spread the range of the grain size values. Grain size characteristics of the dune sands at Barra del Tordo are controlled by selective processes limiting the range in the grain size values in a narrow coastal plain. The most conspicuous grain size characteristics $(\mathrm{Mz}(\varphi)$ and $\sigma(\varphi))$ come from the Carrizal River sands, where sands are similar in the range to their counterpart beach sands but not to the dune sands.

2) The Panuco and Carrizal Rivers are compositionally controlling in part of the petrographic framework of quartz and feldspar contents of the Playa Miramar and Barra del Tordo beach and dune sands. The compositional control of beach and dune sands is due to the influence of other fluvial systems and/or redistributions of quartz fractions in the sands along the coast caused by long shore currents and other coastal processes like deflation/winnowing and reworking of the beach and dune sands. The Soto La Marina River is directly influencing the composition of La Pesca beach sands. However, the Soto La Marina is partially influencing the content of volcanic lithics at $\mathrm{La}$ Pesca beach sands.

3) The Carrizal River sands are depleted in magnetite grain fractions, whereas Barra del Tordo beach and dune sands show concentrations of magnetite especially in the dune sands due to differences in grain sizes between the beach-dune and river sands, deflation of light minerals in the beach and dune sands and little disaggregation of rock fragments by fluvial action. This contrast in composition is also supported by the higher average values of $\mathrm{TiO}_{2}$, $\mathrm{Fe}_{2} \mathrm{O}_{3}$ and $\mathrm{MgO}$ in the Barra del Tordo beach and dune sands compared to the Carrizal River sands, indicating that magnetite has been concentrated by other sources and/or alternative coastal processes (i.e. deflation, winnowing). Furthermore, the Carrizal River sands is lower in Cr values compared to the Barra del Tordo beach and dune sands that is related to the depletion of ilmenite and magnetite in the Carrizal River sands. Similarly, the Carrizal River sands is placed in the intermediate igneous province, which reveals lower $\mathrm{TiO}_{2}, \mathrm{Fe}_{2} \mathrm{O}_{3} \mathrm{MgO}$ and $\mathrm{K}_{2} \mathrm{O}$ contents in the river sands (i.e. discriminant analysis coefficients) than in the Barra del Tordo beach and dune sands. This observation indicates that the Carrizal River has little influence in the composition of the Barra del Tordo beach and river sands.

4) The Eu positive anomaly in the beach and dune sands from the three sites is linked to an increase in the $\mathrm{P} / \mathrm{K}$ ratio. However, in terms of provenance it is likely that the beach and dune sands are derived from felsic to intermediate rocks. Moreover, it is likely that the $\mathrm{Eu}$ positive anomaly is related to the low weathering nature of the sands in a humid climate associated with the presence of marshes. In the Carrizal River sands, the highest $(\mathrm{La} / \mathrm{Lu})_{\mathrm{cn}}$ ratio suggests that quartz enrichment in the river sands compared to their beach and dune sands counterparts. Additionally, the $(\mathrm{Gd} / \mathrm{Yb})_{\mathrm{cn}}$ ratio $>2$ for the Carrizal River sands suggests that river sands are low in HREE concentrations compared to their beach and dune sands counterparts indicating less concentration of heavy minerals as potential carriers of HREE seawards.

\section{Acknowledgements}

We appreciate the assistance of Eduardo Morales de la Garza in the Particle Size Analysis and to Elizabeth Hernández Álvarez for her work on the rare earth elements analysis. This research was partly supported by the Proyecto Papiit INI112811-2 DGAPA-UNAM “Análisis de sedimentos recientes en le costa noreste del Golfo de México: implicaciones para procesos costeros a partir de la presencia de minerales de importancia económica y geoquímica de sedimentos". The second author is grateful to the financial support of the Instituto de Ciencias del Mar y Limnología, Universidad Nacional Autónoma de México, Institutional (No. 616, contribution no. 13) and PAPIIT (No. IA101213, contribution no. 5) Projects.

\section{REFERENCES}

[1] A. Carranza-Edwards and L. Rosales-Hoz, "Grain Size Trends and Provenance of Southwestern Gulf of Mexico Beach Sands," Canadian Journal of Earth Sciences, Vol. 32, No. 12, 1995, pp. 2009-2014. http://dx.doi.org/10.1139/e95-153

[2] A. Carranza-Edwards, "Grain Size and Sorting in Modern Sands," Journal of Coastal Research, Vol. 17, No. 1, 2001, pp. 38-52.

[3] A. Carranza-Edwards, J. J. Kasper-Zubillaga, L. RosalesHoz, E. Morales de la Garza and R. Lozano-Santa Cruz, "Beach Sand Composition and Provenance in a Sector of the Southwestern Mexican Pacific," Revista Mexicana de Ciencias Geológicas, Vol. 26, No. 2, 2009, pp. 433-447.

[4] S. Critelli and E. Le Pera, "Detrital Modes and Provenance of Miocene Sandstones and Modern Sands of the Southern Apennines Thrust-Top Basins (Italy)," Journal of Sedimentary Research, Vol. A64, 1994, pp. 824-835. http://dx.doi.org/10.1306/D4267ED8-2B26-11D7-864800 0102C1865D

[5] L. Folk, "Petrology of Sedimentary Rocks," Austin Texas, Hemphill, 1980.

[6] H. Ibbeken and R. Schleyer, "Source and Sediment," Springer, Berlin, 1991. http://dx.doi.org/10.1007/978-3-642-76165-2

[7] J. J. Kasper-Zubillaga and A. Carranza-Edwards, "Grain Size Discrimination between Sands of Desert and Coastal dunes from Northwestern Mexico," Revista Mexicana de 
Ciencias Geológicas, Vol. 22, No. 3, 2005, pp. 383-390.

[8] J. J. Kasper-Zubillaga and H. Zolezzi-Ruiz, "Grain Size, Mineralogical and Geochemical Studies of Coastal and Inland Dune Sands from El Vizcaíno Desert, Baja California Peninsula, Mexico," Revista Mexicana de Ciencias Geológicas, Vol. 24, No. 3, 2007, pp. 423-438.

[9] J. S. Armstrong-Altrin, Y. I. Lee, S. P. Verma and S. Ramasamy, "Geochemistry of Sandstones from the Upper Miocene Kudankulam Formation Southern India: Implications for Provenance, Weathering and Tectonic Setting," Journal of Sedimentary Research, Vol. 74, No. 2, 2004, pp. 285-297. http://dx.doi.org/10.1306/082803740285

[10] J. S. Armstrong-Altrin, "Provenance of Sands from Cazones, Acapulco, and Bahía Kino Beaches, Mexico," Revista Mexicana de Ciencias Geológicas, Vol. 26, No. 3, 2009, pp. 764-782.

[11] J. J. Kasper-Zubillaga, A. Carranza-Edwards and O. Morton-Bermea, "Heavy Minerals and Rare Earth Elements in Coastal and Inland Dune Sands of El Vizcaino Desert, Baja California Peninsula, Mexico," Marine Georesources and Geotechnology, Vol. 26, No. 2, 2008, pp. 172-188. http://dx.doi.org/10.1080/10641190802258932

[12] M. A. Mange and E. G. Otvos, "Gulf Coastal Plain Evolution in West Louisiana: Heavy Mineral Provenance and Pleistocene Alluvial Chronology," Sedimentary Geology, Vol. 182, No. 1-4, 2005, pp. 29-57. http://dx.doi.org/10.1016/i.sedgeo.2005.07.015

[13] D. R. Muhs, "Mineralogical Maturity in Dune Fields of North America, Africa and Australia," Geomorphology, Vol. 59, 2004, pp. 247-269. http://dx.doi.org/10.1016/j.geomorph.2003.07.020

[14] G. G. Zuffa, "Optical Analysis of Arenites: Influence of Methodology on Compositional Results," G. G. Zuffa, Ed., Provenance of Arenites Dordrecht, Netherlands, pp. 165-189.

[15] K. Sultan and N. A. Shazili, "Geochemical Baselines of Major, Minor and Trace Elements in the Tropical Sediments of the Terengganu River Basin, Malasya," International Journal of Sediment Research, Vol. 25, No. 4, 2010, pp. 340-354

http://dx.doi.org/10.1016/S1001-6279(11)60002-4

[16] S. Saha, S. Banerjee, S. D. Burley, A. Ghosh and P. L. Saraswati, "The Influence of Flood Basaltic Source Terrains on the Efficiency of Tectonic Setting Discrimination Diagrams: An Example from the Gulf of Khambhat, Western India," Sedimentary Geology, Vol. 228, No. 1, 2010, pp. 1-13.

http://dx.doi.org/10.1016/j.sedgeo.2010.03.009

[17] J. Lugo-Hubp, "El Relieve de la República Mexicana," Revista del Instituto de Geología, UNAM, Vol. 9, 1990, pp. 82-111 (in Spanish).

[18] A. Yáñez-Arancibia and J. W. Day, "Environmental SubRegions in the Gulf of Mexico Coastal Zone the Ecosystem Approach as an Integrated Management Tool," Ocean and Coastal Management, Vol. 47, No. 11-12, 2004, pp. 727-757. http://dx.doi.org/10.1016/j.ocecoaman.2004.12.010

[19] A. Fernández-Eguiarte, A. Gallegos-García and J. Zavala-
Hidalgo, "Oceanografía Física (Masas de Agua y Mareas de los Mares Mexicanos) IV.9.1, escala 1: 4000.000, Atlas Nacional de México, México," Instituto de Geografía, Universidad Nacional Autónoma de México, 1 Map, 1992 (in Spanish).

[20] G. Pérez-Villegas, "Wind Sheet IV.4.2, Vientos Dominantes 1:4 000.000. Atlas Nacional de México," Instituto de Geografía, Universidad Nacional Autónoma de México, Ciudad de México, 1990 (in Spanish).

[21] F. J. Pettijohn, P. E. Potter and R. Siever, "Sand and Sandstone," Springer Verlag, New York, 1972.

[22] A. Basu, "Petrology of Holocene Fluvial Sand Derived from Plutonic Source Rocks: Implications to Paleoclimatic Interpretation," Journal of Sedimentary Petrology, Vol. 46, No. 3, 1976, pp. 694-709.

[23] E. Franzinelli and P. E. Potter, "Petrology, Chemistry and Texture of Modern River Sands, Amazon River System," Journal of Geology, Vol. 91, No. 1, 1983, pp. 23-29. http://dx.doi.org/10.1086/628742

[24] G. J. Weltje, "Quantitative Analysis of Detrital Modes: Statistically Rigorous Confidence Regions in Ternary Diagrams and Their Use in Sedimentary Petrology," Earth Science Reviews, Vol. 57, No. 3, 2002, pp. 211-253. http://dx.doi.org/10.1016/S0012-8252(01)00076-9

[25] S. R. Taylor and S. M. McLennan, "The Continental Crust: Its Composition and Evolution,” Blackwell, Oxford, 1985.

[26] B. P. Roser and R. J. Korsch, "Provenance Signatures of Sandstone-Mudstone Suites Determined Using Discrimination Function Analysis of Major-Element Data," Chemical Geology, Vol. 67, No. 1-2, 1988, pp. 119-139. http://dx.doi.org/10.1016/0009-2541(88)90010-1

[27] T. S. Ahlbrandt, "Textural Parameters of Aeolian Deposits," In: E. D. McKee, Ed., A Study of Global Sand Seas, Geological Survey Professional Paper 1052, pp. 21-58.

[28] W. N. Bascom, "The Relationship between Sand Size and Beach Face Slope," Transactions of the American Geophysical Union, Vol. 32, No. 6, 1951, pp. 876-864. http://dx.doi.org/10.1029/TR032i006p00866

[29] J. J. Kasper-Zubillaga, A. Carranza-Edwards and L. RosalesHoz, "Petrography and Geochemistry of Holocene Sands in the Western Gulf of México: Implications of Provenance and Tectonic Setting," Journal of Sedimentary Research, Vol. 69, No. 5, 1999, pp. 1003-1010. http://dx.doi.org/10.2110/jsr.69.1003

[30] J. J. Kasper-Zubillaga, H. Zolezzi-Ruiz, A. C. Edwards, P. G. García, G. V. Ortiz-Zamora and M. Palma, "Sedimentological, Modal Analysis and Geochemical Studies of Desert and Coastal Dunes, Altar Desert, NW México," Earth Surface Processes and Landforms, Vol. 32, No. 4, 2007, pp. 598-508. http://dx.doi.org/10.1002/esp.1402

[31] X. Wang, Z. Dong, J. Zhang, J. Qu and A. Zhao, "Grain Size Characteristics of Dune Sands in the Central Taklimakan Sand Sea," Sedimentary Geology, Vol. 161, No. 1, 2003, pp. 1-14. http://dx.doi.org/10.1016/S0037-0738(02)00380-9

[32] P. E. Potter, "South America and a Few Grains of Sand: Part 1-Beach Sands," Journal of Geology, Vol. 94, No. 3, 1986, pp. 301-319. http://dx.doi.org/10.1086/629031 
[33] S. Ghosh and S. Sarkar, "Geochemistry of Permo-Triassic Mudstone of the Satpura Gondwana Basin, Central India: Clues for Provenance," Chemical Geology, Vol. 277, No. 1, 2010, pp. 78-100.

http://dx.doi.org/10.1016/j.chemgeo.2010.07.012

[34] E. Le Pera and S. Critelli, "Sourceland Controls on the Composition of Beach and Fluvial Sand of the Northern Tyrrenian Coast of Calabria, Italy: Implications for Actualistic Petrofacies," Sedimentary Geology, Vol. 110, No. 1-2, 1997, pp. 81-97. http://dx.doi.org/10.1016/S0037-0738(96)00078-4

[35] W. K. Fletcher, M. Church and J. Wolcott, "FluvialTransport Equivalence of Heavy Minerals in the Sand Size Range," Canadian Journal of Earth Sciences, Vol. 29, No. 9, 1992, 2017-2021. http://dx.doi.org/10.1139/e92-158

[36] J. J. Kasper-Zubillaga, B. Acevedo-Vargas, O. M. Bermea and G. Ortiz Zamora, "Rare Earth Elements of the Altar Desert Dune and Coastal Sands, Northwestern Mexico," Chemie Der Erde_Geochemistry, Vol. 68, No. 1, 2008, pp. 45-59.

http://dx.doi.org/10.1016/j.chemer.2006.05.001

[37] S. M. McLennan, S. Hemming, D. K. McDaniel and G. N. Hanson, "Geochemical Approaches to Sedimentation, Provenance and Tectonics," In: M. J. Johnsson and A. Basu, Eds., Processes Controlling the Composition of Clastic Sediments, Special Paper 284, Colorado Geological Society of America, Boulder, pp. 21-40.

[38] E. R. Force, R. F. Butler, R. L. Reynolds and R. S. Houston, "Magnetic Ilmenite-Hematite Detritus in MezosoicTertiary Placer and Sandstone-Hosted Uranium Deposits of the Rocky Mountains," Economic Geology, Vol. 96, No. 6, 2001, pp. 1445-1453. http://dx.doi.org/10.2113/gsecongeo.96.6.1445

[39] D. García, C. Ravenne, B. Maréchal and J. Moute, "Geochemical Variability Induced by Entrainment Sorting: Quantified Signals for Provenance Analysis," Sedimentary Geology, Vol. 171, No. 1-4, 2004, pp. 113-128. http://dx.doi.org/10.1016/j.sedgeo.2004.05.013

[40] A. Basu and E. Molinaroli, "Provenance Characteristics of Detrital Opaque Fe-Ti Oxide Minerals," Journal of Sedimentary Petrology, Vol. 59, No. 6, 1989, pp. 922-934.

[41] J. D. Grigsby, "Detrital Magnetite as a Provenance Indicator," Journal of Sedimentary Petrology, Vol. 60, No. 6, 1990, pp. 940-951.

[42] R. Nath-Hota, B. Kumar Das, M. Sahoo and W. Maejima, "Provenance Variability during Damuda Sedimentation in the Talchir Godwana Basin, India-A Statistical Assessment," International Journal of Geosciences, Vol. 2, No. 2, 2011, pp. 120-137.

[43] J. Veizer, "Secular Variations in the Composition of Sedimentary Carbonate Rocks II Fe, Mn, Ca, Mg, Si and Minor Constituents," Precambrian Research, Vol. 6, No. 3-4, 1978, pp. 411-449.

[44] N. Etemad-Saeed, M. Hosseini-Barzi and J. S. Armstrong-Altrin, "Petrography and Geochemistry of Clastic Sedimentary Rocks as Evidences for Provenance of the Lower Cambrian Lalun Formation, Posht-e-Badam Block, Central Iran," Journal of African Earth Sciences, Vol. 61,
No. 2, 2011, pp. 142-159.

http://dx.doi.org/10.1016/j.jafrearsci.2011.06.003

[45] R. L. Lawrence, R. Cox, R. W. Mapes and D. S. Coleman, "Hydrodynamic Fractionation of Zircon Age Populations," Geological Society of America Bulletin, Vol. 123, No. 1-2, 2011, pp. 295-305.

http://dx.doi.org/10.1130/B30151.1

[46] J. S. Armstrong-Altrin, Y. I. Lee, J. J. Kasper-Zubillaga, G. Nelson Eby, D. Garcia, A. Carranza-Edwards, V. Balaram and N. L. Cruz-Ortiz, "Geochemical Composition of Beach Sands from the Western Gulf of Mexico, Mexico: Implication for Provenance," Chemie Der ErdeGeochemistry, Vol. 72, No. 4, 2012, 345-362.

http://dx.doi.org/10.1016/j.chemer.2012.07.003

[47] A. I. M. Akarish and A. M. El-Gohary, "Provenance and Source Area Weathering Derived from the Geochemistry of Pre-Cenomanian Sandstones, East Sinai, Egypt," Journal of Applied Sciences, Vol. 11, No. 17, 2011, pp. 30703088. http://dx.doi.org/10.3923/jas.2011.3070.3088

[48] A. J. King, D. G. Wagoneer and M. O. García, "Geochemistry and Petrography of Basalts from Leg 146. Central Pacific Ocean," Proceedings of the Ocean Drilling Program, Scientific Results, Vol. 136, 1993.

[49] M. H. Carr and K. K. Turekian, "The Geochemistry of Cobalt," Geochimica et Cosmochimica Acta, Vol. 23, No. 1-2, 1961, pp. 9-60. http://dx.doi.org/10.1016/0016-7037(61)90087-4

[50] M. J. J. Rahman and S. Suzuki, "Composition of the Neogene Shales from the Surma Group, Bengal Basin, Bangladesh: Implications for Provenance and Tectonic Setting," Australian Journal of Earth Sciences, Vol. 100, 2007, pp. 54-64.

[51] J. V. Owen, K. L. Irwin, C. L. Flint and G. E. Greenough, "Trace Element Constraints on the Source of the Source Silica Sand Used by the Boston and Sandwich Glass Co. (c. 1826-1888)," The Journal of the Society for Industrial Archeology, Vol. 31, 2005.

http://www.historycooperative.org/journals/sia/31.2/owen .html

[52] R. Nagarajan, J. Madhavaraju, R. Nagendra, J. S. Armstrong-Altrin and J. Moutte, "Geochemistry of Neoproterozoic Shales of the Rabanpalli Formation, Bhima Basin, Northern Karnataka, Southern India: Implications for Provenance and Paeleoredox Conditions," Revista Mexicana de Ciencias Geológicas, Vol. 24, No. 2, 2007, pp. 150-160.

[53] R. L. Cullers, "The Chemical Signature of Source Rocks in Size Fractions of Holocene Stream Sediment Derived from Metamorphic Rocks in the West Mountains Region, USA," Chemical Geology, Vol. 113, No. 3-4, 1994, pp. 327-343. http://dx.doi.org/10.1016/0009-2541(94)90074-4

[54] R. L. Cullers, "The Geochemistry of Shales, Siltstones and Sandstones of Pennsylvanian Permian Age, Colorado, USA: Implications for Provenance and Metamorphic Studies," Lithos, Vol. 51, No. 3, 2000, pp. 181-203. http://dx.doi.org/10.1016/S0024-4937(99)00063-8

[55] M. N. Evensen, P. J. Hamilton and R. K. O’Nions, "Rare Earth Abundance in Chondrite Meteorites," Geochimica 
et Cosmochimica Acta, Vol. 42, No. 8, 1978, pp. 11991212. http://dx.doi.org/10.1016/0016-7037(78)90114-X

[56] S. Y. Yang, H. S. Jung, M. S. Choi and C. X. Li, "The Rare Earth Compositions of the Changjiang (Yangtze) and Huanghe (Yellow) River Sediments," Earth and Planetary Science Letters, Vol. 201, No. 2, 2002, pp. 407419. http://dx.doi.org/10.1016/S0012-821X(02)00715-X

[57] P. D. Roy and W. Smykatz-Kloss, "REE Geochemistry of the Recent Playa Sediments from the Thar Desert, India: An Implication to Playa Sediment Provenance," Chemie Der Erde-Geochemistry, Vol. 67, No. 1, 2007, pp. 5568 .

[58] H. W. Nesbitt and G. Young, "Early Proterozoic Climate and Plate Motions Inferred from Major Chemistry of Lutites," Nature, Vol. 279, No. 1, 1996, pp. 715-717. http://dx.doi.org/10.1016/j.chemer.2005.01.006

[59] B. P. Ruxton, "Labile Quartz-Poor Sediments from Young Mountain Ranges in Northeast Papua," Journal of Sedimentary Petrology, Vol. 40, No. 4, 1970, pp. 1262-1270.
[60] D. C. Isidore Ilouga, C. E. Suh and G. R. Tanwi, "Textures and Rare Earth Elements Composition of Banded Iron Formations (BIF) at Njweng Prospect, Mbalam Iron ore District, Souther Cameroon," International Journal of Geosciences, Vol. 4, No. 1, 2013, pp. 146-165. http://dx.doi.org/10.4236/ijg.2013.41014

[61] R. Nagarajan, J. S. Armstrong-Altrin, R. Nagendra, J. Madhavaraju and J. Moutte, "Petrography and Geochemistry of Terrigenous Sedimentary Rocks in the Neoproterozoic Rabanpalli Formation, Bhima Basin, Southern India: Implications for Paleoweathering Condition, Provenance, and Source Rock Composition," Journal of the Geological Society of India, Vol. 70, No. 2, 2007, pp. 297-312.

[62] M. Honda, S. Yabuki and H. Shimizu, "Geochemical and Isotopic Studies of Aeolian Sediments in China," Sedimentology, Vol. 51, No. 2, 2004, pp. 211-230. http://dx.doi.org/10.1111/j.1365-3091.2004.00618.x 